\title{
J. Octaviano e Oscar Guanabarino: "a verdade é uma aposta de lutas"
}

\author{
Humberto Amorim \\ Universidade Federal do Rio de Janeiro \\ humbertoamorim@musica.ufrj.br \\ https://orcid.org/0000-0003-2622-8698
}

\begin{abstract}
Resumo: $\mathrm{O}$ artigo intenta cruzar alguns vestígios das disputas práticas e simbólicas que giraram em torno da música de concerto no Brasil durante as primeiras décadas do século $\mathrm{XX}$, tomando como objeto de estudo a relação entre o compositor, pianista e professor João Octaviano Gonçalves (1892-1962) e o crítico Oscar Guanabarino (1841-1937). Um dos pontos decisivos foi tentar desvelar algumas das camadas soterradas que compuseram o campo de concorrências no qual ambos atuavam, conectando as suas projeções individuais aos interesses de grupo. Com um referencial ancorado em historiadores culturais (CHARTIER, 2002; BOURDIEU, 1996; CERTEAU, 1982) e em diálogo com a literatura brasileira mais recente dedicada ao tema (GOLDBERG; OLIVEIRA, 2019; PASSAMAE, 2017), foram levantadas 50 fontes em jornais e periódicos da época para sustentar as discussões. Os resultados sugerem que ao lado das trajetórias e crenças pessoais se articulam lutas de representatividade mais amplas que são decisivas para ensejar posicionamentos. Por isso, a importância de se relacionar "os discursos proferidos com a posição de quem os utiliza" (CHARTIER, 2002, p. 17) ou, ainda que parcialmente, resgatar "o gesto que liga as 'ideias' aos lugares.” (CERTEAU, 1982, p. 64).
\end{abstract}

Palavras-chave: Oscar Guanabarino, João Octaviano Gonçalves, J. Octaviano, Crítica musical, Lutas de representatividade na música.

\section{J. Octaviano and Oscar Guanabarino: "the truth is a fight bet"}

Abstract: The article intends to cross some vestiges of the disputes that occurred around classical music in Brazil during the first decades of the 20th century, taking as a subject of study the relationship between the composer, pianist and professor João Octaviano Gonçalves (1892-1962) and the critic Oscar Guanabarino (1841-1937). One of the decisive points was to try to unveil some of the buried layers that were part of the field of competition in which both operated, connecting their individual projections to the interests of their groups. With a theoretical background anchored in historians (CHARTIER, 2002; BOURDIEU, 1996; CERTEAU, 1982) and in dialogue with the most recent Brazilian literature dedicated to the subject (GOLDBERG; OLIVEIRA, 2019; PASSAMAE, 2017), fifty sources were raised in newspapers to sustain the discussions. The results suggest that, alongside personal trajectories and beliefs, there are broader symbolic struggles in music that become decisive for taking positions. For this reason, the importance of relating "the speeches given to the position of those who use them" (CHARTIER, 2002, p. 17) or, even if partially, to rescue "the gesture that links 'ideas' to places." (CERTEAU, 1982, p. 64).

Keywords: Oscar Guanabarino, João Octaviano Gonçalves, J. Octaviano, Music Review, Symbolic struggles in music.

\section{João Octaviano Gonçalves: uma introdução}

Natural de Porto Alegre, capital do Rio Grande do Sul, João Octaviano Gonçalves (1892-1962) fez carreira no Rio de Janeiro, onde desenvolveu uma intensa e longeva atividade como concertista, compositor, professor, arranjador e articulador cultural até morrer. Até o momento, são parcas ou inexistentes as notícias sobre os seus antecedentes 
familiares e as vivências de sua infância na cidade natal. Sabe-se, apenas, que J. Octaviano finalizou os estudos secundários no Rio de Janeiro, no Colégio Alfredo Gomes, cujos boletins publicados na imprensa a partir de 1908 nos dão conta de que o artista, então com 16 anos, teve resultados excelentes em álgebra, geometria e desenho ("aprovado com distinção") e foi também um bom aluno em português, francês, inglês, latim e coreografia (“aprovado plenamente”) (O PAIZ, 1908; O PAIZ, 1909).

Outras notícias cotidianas de suas vivências em terras cariocas foram anotadas em periódicos da época, como a inscrição no processo seletivo (sorteio) para alistamento na organização militar do Brasil (O IMPARCIAL, 1917); a tardia expedição de seu título de eleitor, em 1933, quando J. Octaviano já detinha mais de quarenta anos (CORREIO DA MANHÃ, 1933); além das provas realizadas na Inspetoria de Veículos para obtenção da carteira de motorista (O JORNAL, 1922a; 1922b), dado que sugere como o artista foi antenado e aberto às inovações de seu tempo, uma característica que se refletiria, mais adiante, na relação pioneira que estabeleceu entre a música e outras artes, notadamente a dança, a literatura, o teatro e o cinema.

Aliás, a obtenção da habilitação para dirigir, algo ainda raro naquele momento, fez com que Oscar Guanabarino (1841-1937), o mais temido crítico musical brasileiro na passagem entre os séculos XIX e XX, o apelidasse jocosamente de chauffer (motorista em francês) nas diversas crônicas em que - geralmente de forma ácida - tratou de J. Octaviano, sua produção ou atuação no Instituto Nacional de Música. (JORNAL DO COMMERCIO, 1931, p. 2). A análise da relação entre estes dois personagens (que durou quase três décadas) será realizada no presente estudo.

Além da afirmação profissional, também constituiu família no Rio de Janeiro. Em 1921, aos 29 anos, contraiu matrimônio com Isabel Gonçalves Mendes, conforme atestam os editais cíveis (“proclamas") tornados públicos nos jornais da cidade (O IMPARCIAL, 1921). Ambos ficaram efetivamente casados por quase 13 anos, até meados de 1934, quando o requerimento do "desquite amigável" foi publicado na imprensa carioca pela Quarta Vara Cível (JORNAL DO COMMERCIO, 1934a). Aparentemente, o pedido só foi deferido cinco anos depois, quando a mesma Vara toma "por termo o acordo" existente entre as partes (JORNAL DO COMMERCIO, 1939). Não conseguimos reunir maiores informações sobre Isabel Gonçalves Mendes, nem tampouco se guardou algum 
tipo de relação com o ex-marido após o término do relacionamento. Pelo que se depreende de algumas matérias recolhidas em periódicos, o músico teve apenas um filho, Roberto Octaviano Gonçalves, responsável por publicar as notas de falecimento do pai e único membro da família a comparecer às homenagens póstumas que foram realizadas.

Estes dados biográficos iniciais não tem a pretensão de se constituir em um verbete do músico, mas apontar para um primeiro fator decisivo na trajetória musical de $\mathrm{J}$. Octaviano: mais do que a própria cidade do Rio de Janeiro, a sua carreira teve - no início, no desenvolvimento e mesmo após o fim de sua vida - um eixo de ações diversas circunscrito em torno do antigo Instituto Nacional de Música/INM (atual Escola de Música da UFRJ), instituição que participou ativamente da dinâmica da música de concerto no Brasil desde meados do século XIX, o que inclui o seu estabelecimento como polo de referência nacional, a projeção de professores e alunos que acabaram por se tornar nomes reconhecidos historicamente (muitos dos quais conviveram e trocaram experiências diretas com J. Octaviano), além de constantemente oferecer temas e acontecimentos que enredavam as páginas dos jornais, por vezes através de debates acalorados, o que ocorreu especialmente ao longo da primeira metade do século XX.

Mas a relação musical quase intrínseca com o INM não justifica, isolada, a projeção que J. Octaviano alcançou no cenário musical brasileiro, especialmente entre as décadas de 1910 e 1940. É preciso tomá-lo num contexto sociocultural mais amplo, observando como o músico se abriu às janelas de oportunidades oferecidas por seu tempo (seja na relação com as outras artes ou na própria diversidade de suas atividades dentro da música) e de que modo se articulou entre as personagens e/ou personalidades do período. Não foram poucas as vezes em que, ao lado de Heitor Villa-Lobos (1887-1959) ou Glauco Velasquez (1884-1914), J. Octaviano foi considerado pela crítica musical da época como uma das maiores promessas de sua geração (aquela nascida nas últimas duas décadas dos anos oitocentos).

Entre as décadas de 1910 e 1940, a visão preponderante da crítica sobre a atuação de J. Octaviano ratifica o seu mérito como compositor, pianista e professor. Em Música, Doce Música (1933), por exemplo, Mário de Andrade (1893-1945), ao comentar a atuação do músico como solista do concerto para piano de Henrique Oswald (1852-1931), escreveu que teve "o gosto de verificar que o compositor de valor é também um pianista 
a valer" (ANDRADE, 1933, p. 213). Ademais, em outras passagens, sempre o posiciona ao lado de personagens icônicos da música de concerto no Rio de Janeiro. Ao discorrer sobre a disputa mercadológica entre as casas editoriais cariocas e paulistas, o musicólogo desabafa: "Eu, que adoto nas minhas classes as admiráveis produções de Lorenzo Fernandez, Luciano Gallet, Villa-Lobos, F. [J.] Otaviano, sei bem a dificuldade enorme de encontrar as músicas deles aqui [em São Paulo]" (ANDRADE, 1933, p. 336). Ainda em tom de lamento, expressa como o movimento editorial havia perdido força em meados da década de 1930, mais uma vez posicionando J. Octaviano entre aqueles que considerava os expoentes da música brasileira.

Já se foi aquele período, 1928, 1929, brilhantíssimo na produção musical brasileira, em que as casas editoras do Rio expunham mensalmente obras novas de Luciano Gallet, de Lourenço Fernandez, de Otaviano, em que a Casa Chiarato, de S. Paulo, revelava o talento de Camargo Guarnieri, e de Paris a Casa Max Eschig nos abarrotava a sensação de valor nacional, com importantíssimas obras de Villa-Lobos. Tudo parou (ANDRADE, 1933, p. 231).

Portanto, além de confessar que adotava as obras de J. Octaviano em suas aulas, Mário de Andrade confere a ele um lugar entre os seus contemporâneos de ofício mais ilustres. Não parece um indício qualquer de sua relevância naquele período.

\section{Referencial teórico e a bibliografia brasileira dedicada ao tema}

Em um dos seus mais conhecidos livros - A História Cultural: entre práticas $e$ representações -, um dos principais historiadores culturais da atualidade, o francês Roger Chartier (1945), chama a atenção para o papel das lutas de representações nas percepções sociais, defendendo a ideia de que elas são enredadas através de discursos que não são (nem jamais foram e tampouco serão) neutros.

As percepções do social não são de forma alguma discursos neutros: produzem estratégias e práticas (sociais, escolares, políticas) que tendem a impor uma autoridade à custa de outros, por elas menosprezados, a legitimar um projecto reformador ou a justificar, para os próprios indivíduos, as suas escolhas e condutas. Por isso esta investigação sobre as representações supõe-nas como estando sempre colocadas num campo de concorrências e de competições cujos desafios se enunciam em termos de poder e de dominação. As lutas de representações têm tanta importância como as lutas econômicas para compreender os mecanismos pelos quais um grupo impõe, ou tenta impor, a sua concepção do mundo social, os valores que são os seus, e o seu domínio. Ocupar-se dos conflitos de classificações ou de delimitações não é, portanto, afastar-se do social como julgou durante muito tempo uma história de vistas demasiado curtas -, muito pelo contrário, consiste em localizar os pontos de afrontamento 
tanto mais decisivos quanto menos imediatamente materiais (CHARTIER, 2002, p. 17).

Em direção análoga, o sociólogo francês Pierre Bourdieu (1930-2002), em As Regras da Arte, ratifica a perspectiva de que os atores culturais se opõem em lutas de concorrência para definir sentidos e valores em torno das obras consideradas artísticas, reunindo, para tanto, uma ampla gama de agentes (reunidos ou não em "campos") que extrapolam o mero âmbito do artista e de seu trabalho (críticos, colecionadores, conservadores, etc.).

\begin{abstract}
Assim, à medida que o campo [da Percepção Artística] se constitui como tal, a produção da obra de arte, de seu valor, mas também de seu sentido, reduz-se cada vez menos exclusivamente ao trabalho de um artista que, paradoxalmente, concentra cada vez mais os olhares; ela põe em jogo todos os produtores de obras classificadas como artísticas, grandes ou pequenas, célebres, ou seja, celebradas, ou desconhecidas, os críticos, eles próprios constituídos em campo, os colecionadores, os intermediários, os conservadores, em suma, todos aqueles que têm ligação com a arte e, vivendo para a arte e da arte, opõem-se em lutas de concorrência que têm como aposta a definição do sentido e do valor da obra de arte, portanto, a delimitação do mundo da arte e dos (verdadeiros) artistas, e colaboram, por essa próprias lutas, na produção do valor da arte e do artista (BOURDIEU, 1996, p. 330).
\end{abstract}

No Brasil, as décadas finais do século XIX e as iniciais do XX marcam um momento no qual, refletindo as mudanças políticas, econômicas, tecnológicas e socioculturais, a música se vê em meio a um "debate entre os partidários de uma visão estética tradicional e os de uma estética dita modernista", não poucas vezes dirimido "com calor e passionalidade virulenta" (PASSAMAE, 2017, p. 19). Seguindo o pensamento de Bourdieu, é possível sugerir que, no Rio de Janeiro, alguns "campos" musicais começaram a ganhar contornos mais nítidos justamente neste período efervescente de transformações. Neste sentido, talvez não haja caso mais emblemático do que o dos críticos musicais (personagens destacados pelo sociólogo francês como reunidos em um “campo" próprio), uma categoria marcada, em boa parte do Brasil do século XIX, por um diletantismo no qual abundavam matérias ou artigos anônimos (ou assinados com pseudônimos, por vezes jocosos) e análises de essência que não abordavam (ou deixavam em segundo plano) aspectos técnicos, conceituais ou socioculturais das obras, personagens, concertos ou eventos pautados.

A segunda metade do século XIX vê surgir, nos periódicos de várias províncias e regiões, colunas e seções musicais que, paulatinamente, vão aumentando e diversificando o panorama ainda incipiente da crítica musical brasileira. Não se trata, contudo, de 
reivindicar uma mera "evolução". Roger Chartier nos adverte sobre o perigo de incorrermos em uma nova ilusão: "a que leva a considerar o leque das práticas culturais como um sistema neutro de diferenças, como um conjunto de práticas diversas, porém equivalentes", afirmando ainda que "adotar tal perspectiva significaria esquecer que tantos os bens simbólicos como as práticas culturais continuam sendo objeto de lutas sociais onde estão em jogo sua classificação, sua hierarquização, sua consagração (ou, ao contrário, sua desqualificação).” (CHARTIER, 1995, p. 184). Implícita ou explicitamente, o terreno cultural sempre foi palco de batalhas ferrenhas. E os conteúdos produzidos pelos críticos musicais de qualquer tempo, diletantes ou profissionais, não somente estão impregnados de tais disputas, mas são delas parte ativa e dinâmica.

\begin{abstract}
Desvendar seus conteúdos [dos críticos musicais] possui um grande potencial para resgatar à memória questões adormecidas no tempo e, muitas vezes, perdidas nas dinâmicas da história. Trata-se de uma fonte de pesquisa cuja análise não apenas significa 'encurtar os prazos entre a vida das sociedades e sua primeira tentativa de interpretação, mas também a dar a palavra aos que foram os atores dessa história' (LACOUTURE, 1988, p. 217 apud GOLDBERG; OLIVEIRA, 2019a, p. 23-24).
\end{abstract}

Citando Dosse (2003, p. 314), Goldberg e Oliveira ratificam que o estudo da narração dos fatos passados tem relação direta com "as representações que uma época tem de si própria, de sua história e em sua subjetividade", concluindo que "não mais conta-se uma história, mas a representação [ou as representações] que uma época faz de si mesma" (2019e, p. 2-3). Como consequência, a crítica musical seria "uma modalidade de atuação que propaga juízos estéticos, reproduzindo um exercício de poder" (GOLDBERG; OLIVEIRA, 2019a, p. 24).

Na passagem entre os séculos XIX e XX, no Brasil, a figura que mais visivelmente deflagra o campo da música como esta arena de juízos, exercícios de poder e lutas práticas e simbólicas é Oscar Guanabarino de Sousa Silva (1841-1937) ${ }^{1}$. Figura longeva - morreu vítima de um câncer na faringe aos 95 anos -, "foi o mais notável crítico musical de sua época na cidade do Rio de Janeiro, capital do Império e da República, atividade que exerceu durante cerca de meio século. Além de jornalista, foi também comediógrafo [e dramaturgo]. Em atividades pedagógicas, foi professor de piano" (PASSAMAE, 2017, p.

\footnotetext{
1 "Embora Sacramento Blake, no seu Diccionario Bibliographico Brazileiro (1900), informe ter Oscar Guanabarino nascido em 1851, o que é reverberado por Grangeia (2005) e Passamae (2014), em entrevista concedida para O Malho, em 13 de setembro de 1934, o próprio crítico afirma ter nascido em 1841" (GOLDBERG; OLIVEIRA, 2019a, p. 17).
} 
33). O ofício de crítico de arte foi exercido quase ininterruptamente entre 1879-1936, exatamente o ínterim no qual borbulham mudanças estruturais (musicais ou não) que abalam e reconfiguram as dinâmicas socioculturais brasileiras.

\begin{abstract}
Sua longevidade o colocou frente às mudanças ideológicas e estéticas ocorridas no Brasil em um período de intensas transformações: do Segundo Império à Primeira República e desta ao Governo Provisório; do romantismo às correntes modernistas e nacionalistas; do cultivo da ópera ao estabelecimento da música de concerto; do diletantismo à profissionalização musical; entre outras. O posicionamento frente a essas questões está registrado em suas atividades jornalísticas, convertendo-o não apenas em uma testemunha privilegiada, mas também colocando-o como um dos atores da história artística e musical do Brasil na virada dos séculos XIX-XX, isto é, durante a Belle Époque (GOLDBERG; OLIVEIRA, 2019a, p. 17).
\end{abstract}

Ao mesmo tempo em que dá definitivamente uma face visível à crítica musical (e ao crítico), Oscar Guanabarino foi responsável por incutir nos debates musicais de seu tempo questões que iam muito além dos aspectos técnicos das obras ou perfis biográficos de seus escolhidos, perfilando as análises com as suas visões sobre estética, moral, ética, política, educação, economia, etc. Defendia suas posições de forma incisiva e quase sempre intransigente: "não se pode perder de vista que Guanabarino foi um grande polemista e, assim, agente de controvérsias" (PASSAMAE, 2017, p. 31).

Nesta pesquisa, não se pretende esmiuçar aspectos biográficos ou globais relacionados à trajetória e atuação de Guanabarino, um trabalho já competentemente desempenhado por uma ampla gama de estudiosas (os) musicais, dentre eles Goldberg e Oliveira (2019a; 2019b; 2019c; 2019d; 2019e) $)^{2}$, Passamae (2013), Giron (2004), apenas para mencionar alguns dos mais recentes. ${ }^{3} \mathrm{O}$ que intentamos é destacar a posição de Guanabarino como uma espécie de antena parabólica capaz de atrair e refletir algumas das contradições de seu tempo, deflagrando o campo das lutas práticas e simbólicas que ocorreram, durante mais de meio século (1879-1937), em torno da música no Brasil.

Um dado importante é que as posições enfáticas de Guanabarino nos deixam perceber não apenas o bojo dos pensamentos que defendia, mas também aqueles que eram

\footnotetext{
${ }^{2}$ Luiz Guilherme Goldberg, professor da Universidade Federal de Pelotas (UFPEL), coordenou um amplo projeto de pesquisa que resgatou, em quatro volumes, as críticas de Guanabarino escritas para o jornal $\mathrm{O}$ Paiz entre 1884 e 1917. Com quase 1.900 páginas de transcrição, este audacioso resgate documental sobre Guanabarino se encontra gratuitamente disponível, desde 2019, no seguinte endereço eletrônico: https://wp.ufpel.edu.br/criticamusical/oscar-guanabarino/antologia-o-paiz/ Acesso: 14 ago. 2020.

${ }^{3}$ Destaca-se também a dissertação de Grangeia (2005), que debulha as críticas de Guanabarino mais relacionadas às artes plásticas, oferecendo um panorama mais amplo da atuação e do pensamento do personagem para além da música.
} 
contrários (ou complementares) a ele, o que se pode depreender a partir das reações que suas opiniões suscitavam no meio artístico. Em torno de si, concentravam-se tanto as ideias musicais que professava quanto aquelas que abominava (sua vinculação ainda hoje ao nome de Heitor Villa-Lobos é um exemplo peremptório do fato), o que torna seus escritos uma projeção singular - ainda que parcial - dos períodos em questão.

Goldberg e Oliveira chamam a nossa atenção para o fato de como, algumas vezes, as intensidades de tais embates atravessavam o campo ideológico do pensamento e das palavras para se converter em propostas de duelos práticos, advindas de colegas de profissão atingidos por suas análises:

O constrangimento gerado por algumas críticas de Oscar Guanabarino resultou em desafios curiosos. Um deles foi proposto pelo professor Miguel Cardoso [...]: um duelo artístico. 'Lanço-lhe o repto para um duello artistico em uma das salas do imperial conservatorio de musica, e perante uma commissão [....]'. Não é o critico d'A Semana ou o professor da Escola Normal da côrte quem desafia ao critico d'O Paiz. E' o professor de musica Miguel Cardoso, que deseja encontrar-se com o professor de piano Oscar Guanabarino (GOLDBERG; OLIVEIRA, 2019a: 19).

Note-se que Miguel Cardoso também é crítico (“d'A Semana") e professor de uma instituição prestigiada (“A Escola Normal da corte"), o que demonstra como a pena ferina de Guanabarino era capaz de catalisar e refletir também os que pensavam de forma divergente. Os autores acrescentam que "outros dois [embates] resultaram efetivamente em provocações para um duelo: o primeiro foi lançado pelo músico Carlos de Mesquita, em 1890 (O SENHOR, 1890, p. 1); o segundo, pelo dramaturgo Roberto Gomes, em 1912” (DUELLO, 1912, p. 1 apud GOLDBERG; OLIVEIRA, 2019a, p. 20).

São indícios inequívocos do comprometimento de tais personagens nas lutas simbólicas que envolvem os objetos artísticos, corroborando o antevisto por Bourdieu: “os historiadores da arte e os teóricos da estética, estão comprometidos, sem o saber, ou sem tirar disso, em todo caso, todas as consequências, nas lutas em que se produzem o sentido e o valor da obra de arte: são enredados pelo objeto que acreditam tomar como objeto" (BOURDIEU, 1996, p. 330). Se, por um lado, o sociólogo nos adverte que a consequência disto é a permanência da ciência das obras de arte em um estado de "infância", por outro, é inegável que também nos permite depreender as divergências e contradições que a crítica e seus personagens encerram na tentativa de defender uma determinada essência artística universal (inexistente, em última instância). 
Nas décadas iniciais do século XX, o principal comentador das atividades de João Octaviano Gonçalves (1892-1862) foi justamente o personagem que, em mais de cinquenta anos de atuação (1879-1937) na imprensa carioca, tornara-se o crítico musical mais incisivo e polêmico do Rio de Janeiro: Oscar Guanabarino. Apesar de figura praticamente desconhecida nos dias de hoje, o compositor, pianista e professor J. Octaviano - seu nome artístico - foi um dos agentes musicais mais ativos e comentados nas colunas musicais brasileiras entre as décadas de 1910 e 1940.

Ao aprofundar as investigações sobre este músico gaúcho e que fez carreira no Rio de Janeiro, nos surpreendemos não somente com o volume de matérias levantadas que tomaram como pauta suas ideias, obras, concertos e atividades diversas, mas também com a enorme quantidade de peças - cerca de 400 - para diversas formações (de óperas e bailados a peças para instrumento solista; de sinfonias e cantatas a quase 100 peças para canto e piano) que suscitamos em acervos públicos e privados durante os últimos anos, muitas das quais sobreviventes apenas em manuscritos autógrafos ou cópias únicas.

Um estudo biográfico e outro especificamente dedicado a esta portentosa produção estão em andamento, de maneira que, no presente artigo, nos concentraremos em resgatar parte do que fora escrito sobre J. Octaviano na imprensa carioca, com ênfase no material apreendido entre as décadas de 1910 a 1940, justamente o período que encerra o auge de sua carreira e as últimas décadas de atuação de Guanabarino como crítico musical.

Ao cruzar a trajetória destes dois personagens, intentamos atingir inicialmente dois objetivos: promover uma primeira tentativa de resgate de um personagem musical obliterado - J. Octaviano -, muito embora tenha sido continuamente projetado pelos jornais e articulistas de seu tempo como um dos principais atores da cena musical do Rio de Janeiro de então ${ }^{4}$; depois, tomar a sua relação com Oscar Guanabarino como um dos

\footnotetext{
4 De 1911 até a década de 1940, J. Octaviano foi alvo ininterrupto de matérias que, em maior ou menor grau, respaldavam as suas atividades como compositor, pianista e professor. No auge da vida jovem e adulta, sua agenda impressionava pelo volume de tarefas e realizações, um dado por muitas vezes destacado na imprensa da época. Eis alguns exemplos: "O maestro Octaviano Gonçalves é uma das maiores afirmações musicais do Brasil de todos os tempos. Nas Gerações mais recentes, só comparável a Glauco Velasquez, cuja morte prematura roubou à música brasileira um vulto dos mais raros, ele se destaca e cresce como o cultor de uma arte austera, sem pretensões, mas original e profunda. Só os grandes mestres podem ombrear com ele: Oswald, Nepomuceno, Braga e poucos outros que já passaram dos cinquenta anos. Porque, entre os novos, si os há de talento, nenhum estudou a sério [provável referência a Villa-Lobos], bastando afirmar que Octaviano Gonçalves é o único aluno que realizou o 'curso completo' do Instituto Nacional de Música. Trabalhador infatigável e idealista, as vitórias de sua carreira estimulam-no cada vez mais, muito ao contrário do que comumente se dá". (A.B.C., 1918, p. 16); "O maestro J. Octaviano é uma
} 
muitos possíveis exemplos de lutas simbólicas travadas dentro do campo da música brasileira de concerto durante as primeiras décadas do século XX, envolvendo, dentre outras pautas, questões institucionais, políticas, estéticas e morais.

A evidenciação destas lutas nos recorda que toda síntese é, por natureza, potencialmente silenciadora. Nossa perspectiva é a de que os embates em torno de um campo podem, talvez, nos contar muito mais sobre as idiossincrasias de um determinado tempo e seus personagens do que as eventuais visões cristalizadas que resultam de tais sínteses, muitas vezes forjadas por pequenos e privilegiados grupos que orientam (ou tentam orientar, ao menos) a direção da gangorra que pendula entre aqueles que merecem ser lembrados e os que devem ser esquecidos. Num só golpe, portanto, gangorra salvífica e mortífera.

Uma das possíveis tarefas da musicologia é equilibrar o pendor desta balança, revelando alguns de seus tentáculos ocultos e desvelando os interesses, limitações, contradições, paradoxos, estratégias e táticas que, explícita ou implicitamente, neles operam.

\section{J. Octaviano e a pena ferina de Guanabarino}

Segundo Goldberg e Oliveira, uma das possíveis abordagens para o estudo da crítica (e dos críticos) é a da "história imediata, que visa entender como esses atores retratam a sua realidade, ou parte dela, colocando-se como porta-vozes de uma coletividade" (2019e, p. 2-3). Se houve alguém que, como crítico musical, tentou incorporar esta condição de porta-voz da coletividade, foi Oscar Guanabarino, personagem que remete à pergunta que realiza o narrador de O Processo, de Franz Kafka,

\footnotetext{
das maiores actividades do nosso meio artístico [e] vem desde muito aparecendo constante nos cartazes" (O IMPARCIAL, 1925, p. 6); "dentre os nossos músicos, o que mais tem se apresentado ao público do Rio de Janeiro", recolhendo "aplausos que se dividiam para o mestre do teclado e para o compositor" (A.B.C, 1927, p. 10); "Tomou parte durante o ano em 14 concertos diferentes [...]. Pelo que aqui fica narrado, vêse que o professor J. Octaviano é um artista que sabe dignificar a sua arte com o concurso do seu talento e com a colaboração da sua vontade que é irredutível. R. B." (O JORNAL, 1931ª , p. 5); "Com as minhas palavras poderão concordar os mais entendidos, tão claro e evidente é o motivo que as inspira. Entretanto, ellas constituem uma humilde manifestação de quem aprendeu a admirar conscienciosamente o professor J. Octaviano, que há de ver sempre o seu nome gravado com letras de ouro, na página mais preciosa da História da Música, em nosso Paiz! Aurora do Céo A. Lima." (CORREIO DA MANHÃ, 1940, p. 29).
} 
quando o protagonista do romance, Joseph K., encontra-se diante de uma difícil escolha: “Será que K. poderia representar, sozinho, toda a comunidade?” (KAFKA, 2009, p. 239).

Considerado pelos estudiosos do tema como o "fundador da crítica especializada no Brasil" (GIRON, 2004, p. 16), “o primeiro e mais importante crítico profissional brasileiro de arte (PASSAMAE, 2017, p. 18) e um personagem que, embora frequentemente contestado e envolto em polêmicas, detinha "convicções e conhecimento musical" capazes de respaldar "o respeito com que suas colunas eram recebidas" (GOLDBERG; OLIVEIRA, 2019a, p. 20), Guanabarino atrelou a si, desde as últimas décadas do século XIX, a posição simbólica do juiz capaz de decidir não somente o que tinha ou não valor artístico, mas também o que era ou não eticamente correto em relação às artes e seus meandros. Nem sempre venceu as apostas, mas o testemunho escrito em 1897 pelo colega de profissão Cesare Bonafous (em sua coluna Solfejando, do jornal Cidade do Rio) é um indício assertivo da posição simbólica que o crítico já ocupava no campo musical do Rio de Janeiro:

\footnotetext{
Seu juizo critico póde se considerar a ultima ratio; o golpe final desfechado na vida artistica do infeliz. Fallou Guanabarino, basta de palavra.

Artista que elle amparou com a custodia de um elogio seu, póde logo contar com os favores e as sympathias do publico. Tambem o desventurado que não cahiu sob a égide protectora do paranympho das multidões, póde tambem contar com o de profundis, porque está irremediavelmente perdido. Oscar não gostou do musico, este que abandone barcos e rêdes e vá cuidar de outra vida.

Aqui está a origem de tantos odios contra esse inoffensivo moço, tão importante nas suas criticas respeitaveis quanto destemido soldado nas suas pontarias patrioticas.

Soldado e musico-jornalista. Eis as duas feições mais sympathicas por que se nos apresenta (BONAFOUS, 1897, apud GOLDBERG; OLIVEIRA, 2019a, p. 20).
}

A terminologia utilizada para descrevê-lo se configura em mais um sintoma de como tais agentes eram, antes de tudo, a expressão crua das lutas de representações que então ocorriam em torno da música. Na linha de frente dos embates, Guanabarino era um "destemido soldado" e estava em dia com as suas "pontarias patrióticas". Além disso, a sua posição nas trincheiras era a de ultima ratio - expressão em latim que pode ser traduzida livremente por "última razão" -, um "inofensivo moço", mas de cuja pena pululava o "golpe final" com o poder de decidir quem poderia ou não seguir a carreira musical. Ora, não é um vocabulário próprio das guerras? 
Entretanto, a questão tem mais nuances do que o preto e o branco sugerido por Bonafous. Primeiro, porque Guanabarino não estava sozinho no campo de batalhas (nem como representante de uma categoria e tampouco como sujeito individual) e enfrentava contrapesos de todas as espécies (estéticos, estilísticos, ideológicos, institucionais, éticos, etc.), muitas vezes tendo seus discursos negados pela força prática da realidade (vide o caso emblemático de sua relação com Villa-Lobos). Não era, portanto, infalível.

Depois, porque embora parte dos estudiosos confira a Guanabarino uma invariável honestidade intelectual ${ }^{5}$, o estudo do campo da crítica musical nos impinge a necessidade de "aprofundar-se e prospectar as representações que estão aí reproduzidas, para além do juízo ao artista ou à obra considerada" (GOLDBERG; OLIVEIRA, 2019a, p. 24). Ou seja, é preciso reconhecer que ao lado da crença pessoal (e não duvidamos que Guanabarino fosse honesto com suas convicções) operam outros interesses subliminares (sejam particulares ou de grupo) que, nos jogos de poder e representação, são decisivos para as tomadas de posição.

As representações do mundo social assim construídas, embora aspirem à universalidade de um diagnóstico fundado na razão, são sempre determinadas pelos interesses de grupo que as forjam. Daí, para cada caso, o necessário relacionamento dos discursos proferidos com a posição de quem os utiliza (CHARTIER, 2002, p. 17).

Conforme já observamos, um dos objetos deste estudo é avaliar como a análise da atuação de Guanabarino é decisiva para compreendermos alguns dos movimentos dentro deste tabuleiro movediço das lutas simbólicas que, naquele momento, ocorriam no campo musical brasileiro. No Rio de Janeiro, entre as décadas finais do século XIX e as iniciais do XX, um dos catalizadores mais emblemáticos de tais discussões foi o Instituto Nacional de Música (INM), instituição que quase sempre teve, em Guanabarino, um comentador e crítico contumaz.

Já são notórios, por exemplo, os embates de Guanabarino com dois dos mais ilustres personagens da música de concerto brasileira, ambos ocupantes do cargo de diretor do Instituto Nacional de Música por longos períodos: Leopoldo Miguez (1850-1902) e Alberto Nepomuceno (1864-1920).

\footnotetext{
5 “" [...] independente dos resultados de seus embates polêmicos, Guanabarino pautou-se, invariavelmente pela honestidade intelectual e de princípios forjados pela sua formação como artista, como intelectual e como indivíduo, além da ansiedade de ver estabelecida uma cultura erudita a partir desses princípios." (PASSAMAE, 2017, p. 32).
} 
Figura controversa, [...] não faltaram escritos polêmicos e irônicos, destacando-se por exemplo, aqueles destinados a professores do Instituto Nacional de Música ou a músicos a eles ligados, quer estética, quer afetivamente. Desse Instituto, entre seus destinatários está Leopoldo Miguez e sua gestão como primeiro diretor da instituição, ou mesmo o compositor Alberto Nepomuceno (1864-1920), cujas críticas renderam inúmeras páginas n'O Paiz (GOLDBERG; OLIVEIRA, 2019a, p. 20).

Assim, não parece ocasional que o olhar de Oscar Guanabarino sobre J. Octaviano tenha se tornado mais ácido à medida que a relação deste com o Instituto Nacional de Música se aprofundava. O crítico o pautou pela primeira vez quando ainda era articulista do jornal O Paiz, função que exerceu de 1884 a 1917 ao assinar a coluna Arte e Artistas. O fato ocorreu precisamente em maio de 1913, quando Guanabarino se dedicou a analisar pela primeira vez a produção de Glauco Velásquez (1884-1914), logo após uma audição com 11 de suas obras. Na condição de pianista que começava a ganhar projeção e respeito no ambiente musical carioca, J. Octaviano foi o responsável por interpretar uma destas peças - o Prelúdio e Scherzo op. 46 - em uma atuação que recebeu os melhores elogios do crítico.

O Sr. Octaviano Gonçalves, cujo talento apreciámos quando executou o Concerto em mi bemol, de Beethoven, num dos concertos symphonicos, nesta capital, incumbiu-se de apresentar o Preludio e Scherzo, op. 46, trabalho este de grande originalidade e muito difficil, tendo sido perfeitamente interpretado pelo alludido pianista, discipulo do maestro compositor Henrique Oswald, que, além desse educando que tanto o honra, apresentou um outro, o Sr. Rubens Figueiredo [...] (O PAIZ, 1913a, p. 3). ${ }^{6}$

Note-se que Guanabarino destaca não somente a perfeita interpretação de $J$. Octaviano, mas também que já apreciava o seu "talento" desde ocasiões passadas, ratificando que o pianista honrava o nome de seu ilustre mestre, Henrique Oswald (18521931). As duas questões - ter ou não talento e honrar ou não a cátedra de Oswald - são emblemáticas na guinada retórica do discurso que o crítico dedicou ao músico com o passar do tempo.

Naquela ocasião, em maio de 1913, a relação de J. Octaviano com o Instituto Nacional de Música ainda era a do promissor aluno na classe pianística de um dos raros professores que, sendo ligados à instituição, gozava do respeito e da simpatia de Guanabarino. No ano seguinte, logo após se formar conquistando o primeiro prêmio de piano e a medalha de ouro (disputada com estudantes de todos os instrumentos) no

\footnotetext{
${ }^{6}$ Esta fonte já tinha sido transcrita por Goldberg e Oliveira (2019d:125-127) no quarto volume das Transcrições Guanabarinas: antologia crítica - O Paiz (1884-1917).
} 
prestigiado certame anual do Instituto, J. Octaviano ingressou como livre-docente da casa, passando a ser referenciado na imprensa carioca como o "jovem professor" (O PAIZ, 1914c, p. 3).

Não é novidade que Guanabarino foi um crítico feroz das regras e critérios de seleção da maioria dos concursos para professor do Instituto que acompanhou ${ }^{7}$, o que também incluía questionamentos sobre o papel dos diretores nas seleções, o questionamento da capacidade dos membros da banca e o mérito (ou a eventual falta dele) dos escolhidos. A análise do concurso para livre-docente de canto realizado em 1913, por exemplo, revela o quão o tema era caro a Guanabarino e como possíveis irregularidades eram perscrutadas e denunciadas pelo crítico sem qualquer receio, deflagrando o jogo de interesses e forças que se articulavam em torno das disputas pelos cargos.

\begin{abstract}
Não é um boato o que corre entre os musicos desta capital, relativamente ao concurso para a livre docencia da arte de canto no Instituto Nacional de Musica. Não é boato porque os factos e argumentos são apontados e sabese exactamente o que se tem passado a respeito.

Assegura-se, e é provável, que a commissão composta de professores da aula de canto deu um parecer inepto e vergonhoso sobre a these apresentada pelo pretendente maestro Enrico Borgongino, disparatando como era natural sobre questões para as quaes nenhum delles tem competencia para se manifestar.

O boato consiste ainda num facto que não nos parece muito regular, depois da promessa de viver ás claras, e vem a ser que a secretaria do interior, de accordo com o director do instituto, pretende occultar, archivando, o parecer da commissão, a réplica do pretendente e a tréplica dos professores daquelle estabelecimento.

A culpa desse parecer eivado de disparates monstruosos provém do director, que, diante da these apresentada, devia ter se dirigido ao digno ministro Dr. Rivadavia Correia, pedindo uma commissão especial, alheia ao instituto, para estudar e dar parecer sobre um trabalho cujo assumpto esses professores desconhecem completamente.

Cita-se, por exemplo, que o relator da commissão, cantor da moda nos salões do Rio, escreveu ser o timbre um caracteristico physiologico do som; o autor da these rebateu semelhante disparate e, no entanto, o disparatado parecer foi mantido, negando-se ao interessado cópia por certidão dessa tréplica, que deve ser publicada e analysada para deixar a descoberto o valor scientifico desses professores officiaes, assignando muitos delles de cruz, pareceres que envergonham a idoneidade de uma congregação ${ }^{8}(\mathrm{O}$ PAIZ, 1913b, p. 3).
\end{abstract}

Não encontramos referências na imprensa carioca do período (de Guanabarino ou de quaisquer outros articulistas) questionando a legitimidade do ingresso de J. Octaviano

\footnotetext{
${ }^{7}$ Inclusive chegando a se envolver em polêmicas como parte do júri, conforme atesta a crônica $U m$ escândalo artístico, publicada em sua coluna Artes e Artistas em junho de 1917. (GOLDBERG; OLIVEIRA, 2019d, p. 242-243).

${ }^{8}$ Esta fonte já tinha sido transcrita por Goldberg e Oliveira (2019d: 125) no quarto volume das Transcrições Guanabarinas: antologia crítica - O Paiz (1884-1917).
} 
como livre-docente do Instituto nos anos subsequentes à sua formatura. Em princípio, apesar de jovem, o músico gozava de prestígio e tinha suas capacidades como músico amplamente reconhecidas pelos críticos.

No entanto, a guinada de Guanabarino em relação a Octaviano parece ter acontecido justamente após a atuação deste último como membro do júri de um dos concursos para professor de piano realizados na instituição. Já em meados da década de 1910, o crítico havia se convertido no maior deslegitimador tanto dos certames que conferiam primeiros prêmios e medalhas aos alunos do Instituto (que Guanabarino julgava terem sido banalizados $^{9}$ ) quanto aos concursos para provimentos de seus professores. Neste contexto, em abril de 1921, Guanabarino critica duramente as provas realizadas para preenchimento de duas vagas na cátedra de piano, um certame que teve J. Octaviano no júri, reverberando o cumprimento de uma determinação federal que autorizava somente os próprios professores do Instituto a comporem a banca.

[...] Toda a gente sabe que o director do Instituto recebeu um aviso do ministério a que está sujeito determinando que a mesa examinadora, para esse concurso, fosse constituída exclusivamente por professores daquelle estabelecimento.

Qual o fim ou o intuito desse aviso?

A maledicência póde pensar, pelo menos, que havia interesse em affastar os juízes tidos como severos e capazes de alterar o plano de distribuir as cadeiras como previamente se assentara. [...]

Fez parte da mesa examinadora o professor Octaviano Gonçalves, sempre em evidencia pela sympathia que lhe vota o diretor.

O ilustre examinador já tem produzido algumas anedoctas humorísticas, durante os exames. A penúltima foi a seguinte:

$\mathrm{Na}$ occasião do julgamento do exame de piano de uma alumna, um dos professores propos a nota de distincção para essa senhorinha; mas o $\mathrm{Sr}$. Octaviano Gonçalves oppos-se, sob o fundamento de haver a examinadora executado não como uma discipula e sim como uma concertista!

Se isso não é comico não póde deixar de ser doloroso, dispensando commentarios.

Pois bem. Na prova do ultimo concurso realizado sexta-feira, 8 do corrente [abril de 1921], o Sr. Octaviano Gonçalves perguntou ao candidato Rossini de Freitas o que era e como se empregava o 'meio pedal'. [...]

O Sr. Octaviano Gonçalves não entende nada de pedal; e tanto isso é uma verdade que as suas composições impressas estão cheias de indicações erradas.

\footnotetext{
${ }^{9}$ Em artigo de 1916 intitulado de Instituto Nacional de Música, o crítico professa: "O instituto, ou o seu director, julga que é imprescindivel dar todos os annos primeiros premios aos seus alumnos, como se aquella casa só fosse frequentada por genios musicaes; de modo que essa distincção tornou-se tão vulgar que nada mais representa, tendo perdido a sua importancia. O Instituto do Rio de Janeiro, na sua relativamente curta existencia, tem dado mais primeiros premios do que o Conservatorio de Paris, que vive ha mais de um seculo. A admissão ao concurso devia ser o producto de uma selecção; mas tudo concorre e todos são premiados" (O PAIZ, 1916b, p. 4 apud GOLDBERG; OLIVEIRA, 2019d, p. 207).
} 
Mais ainda. O maior defeito do Sr. Octaviano Gonçalves, como pianista, é justamente no emprego do pedal, facto que pusemos em evidencia a proposito do seu 'recital', e defeito que as alumnas do Instituto notaram e notam com assombro (JORNAL DO COMMERCIO, 1921, p. 2).

Já tendo participado anteriormente de bancas polêmicas nos concursos para professor da casa, é possível que Guanabarino falasse de si próprio quando sugeriu que a determinação do Ministério federal (que albergava o Instituto) impedia o chamamento de "juízes tidos como severos" e capazes de alterar os planos supostamente préestabelecidos. De fato, o impedimento de um julgador externo se prefigura em ato completamente questionável, inclusive desvelando que as disputas por espaços musicais institucionais alcançavam instâncias superiores de poder.

Neste caso específico, a indignação do crítico recai duplamente sobre o então jovem professor Octaviano, um dos membros internos da banca que eventualmente poderia ceder lugar para um partícipe externo: primeiro, moralmente, ao sugerir que o músico teria produzido "anedotas humorísticas" no ambiente musical do Rio de Janeiro ao não julgar honestamente a prova de uma das alunas de piano do Instituto; depois, tecnicamente, ao acusá-lo de fazer uma pergunta "tola" sobre a aplicação de meio-pedais, refutando os seus conceitos e explicações e ainda afirmando que ele não dominava o tema, o que se podia notar nas diversas "indicações erradas" de suas composições publicadas.

Depois disso - e apesar do começo de relação promissor entre ambos -, o olhar do crítico para o compositor, intérprete e professor só piorou. Ao longo da década de 1920, para além das duras críticas, as crônicas dedicadas a J. Octaviano passaram a ter um tom flagrantemente debochado, inclusive com o emprego de apelidos pejorativos. O caso mais emblemático foi o do evento intitulado de Música Psíquica, um grande concerto com obras sinfônicas de J. Octaviano, idealizador, articulador e regente de uma apresentação que contou com a participação de 130 músicos (entre membros da orquestra, coros, fanfarras e solistas) e dominou a cena na imprensa carioca por três meses, entre setembro e dezembro de 1926.

Com lotação máxima do Theatro Lyrico (2.500 pessoas), o acontecimento dividiu as opiniões entre louvores e ressalvas (dirigidas sobretudo ao conceito expresso no título), mas foi de Guanabarino a voz mais ácida desde a divulgação das notas programáticas que anunciavam o concerto: "E para rir temos o humorismo psychico do Sr. J. Octaviano, de quem já publicamos uma lenga-lenga que elle próprio não entendeu e muito menos nós. 
[...] Nas artes, Sr. Bibliothecario ${ }^{10}$, deve-se evitar o ridículo. Oscar Guanabarino. (JORNAL DO COMMERCIO, 1926b, p. 2). No dia seguinte ao evento, ocorrido em 02 de novembro de 1926 (dia de finados), ainda reservou os últimos parágrafos de sua coluna para classificar, em tom de descaso, o concerto como "um bocejo em vários tons".

\begin{abstract}
[...] Sem tempo para desenvolver uma chronica especial sobre a 'Musica psychica', do Sr. Octaviano Gonçalves, executada hontem no Theatro Lyrico, podemos resumir a nossa impressão em poucas palavras: $U m$ bocejo em varios tons!

$\mathrm{O}$ autor progrediu muito na instrumentação: mas não nasceu artista nem possue cultura artistica. As suas partituras executadas hontem, são monotonas e sem idéas musicaes. A parte orchestral bem feita, bem cuidada: a parte melódica de uma infantilidade sem graça.

Um dos numeros do programma - 'Poema da Vida', foi anunciado como 'Poema e musica de J. Octaviano': mas se tal poema é em verso - os versos estão errados - e se foi escripto em prosa não o foi em prosa rythmada, de modo que a parodia [prosódia?] musical resentia-se não poucas vezes.

Somos obrigado[s] a repetir a frase de um dos nossos últimos folhetins: nas artes é preciso evitar o ridiculo. Oscar Guanabarino. (JORNAL DO COMMERCIO, 1926c, p. 2).
\end{abstract}

Ou seja, em pouco mais de uma década, houve uma guinada contundente no olhar do crítico sobre o músico: se antes Guanabarino apreciou o talento e a atuação pianística de J. Octaviano como solista de um exigente concerto para piano de Beethoven (e sem reclamar do uso dos pedais), agora defende que ele não "nasceu artista e nem possui cultura artística"; se antes o compositor era um discípulo que honrava a cátedra de Henrique Oswald, agora se convertera em um artista que não era para ser levado a sério e que precisava se esforçar para evitar o ridículo. A significativa mudança de postura pode ter tido diversas causas (inclusive uma legítima reavaliação de seus méritos musicais), mas é muito provável que a múltipla atuação de J. Octaviano dentro do Instituto Nacional de Música tenha agravado o juízo percuciente que o crítico passou a lhe dedicar.

Como já observado, embora hoje seja mais conhecido por suas ferozes críticas dirigidas a nomes ilustres da música brasileira, especialmente Heitor Villa-Lobos (18871959), Guanabarino também foi um mordaz comentador de quase tudo o que envolvia o Instituto Nacional de Música, incluindo os predicados e atividades de seus professores. $\mathrm{Na}$ primeira vez em que J. Octaviano aparece em sua coluna na década de 1930, por

\footnotetext{
${ }^{10}$ Uma alusão ao período em que J. Octaviano assumiu o posto de bibliotecário do Instituto Nacional de Música. Numa tentativa de desqualificar sua atuação como músico, Guanabarino seguidamente se dirigia a ele com apelidos informais ("Zé Octaviano") ou o estigmatizava como portador de outros ofícios (chauffer, arquivista, bibliotecário).
} 
exemplo, o crítico se refere à instituição como um "leproso estabelecimento", justificando o fato de não ter sido convidado para escrever no periódico Illustração Musical por este ser um "órgão oficial do Instituto".

A Illustração Musical, além do exposto, foi fundada pelo professor Lorenzo Fernandez, cathedratico de qualquer coisa, graças à prevaricação do Sr. Fertin de Vasconcellos logo que se deu o falecimento do professor Frederico de Nascimento, cathedratico do curso de harmonia (JORNAL DO COMMERCIO, 1930, p. 2).

Em boa parte deste longo artigo, sobressaltam críticas a dois dos mais ilustres professores da casa: Oscar Lorenzo Fernández (1897-1948), a quem Guanabarino acusava de ter entrado no Instituto sem concurso e através de conchavos, uma vez que tinha sido um aluno com "nota baixa no exame de contraponto"; e Alfredo Fertin de Vasconcellos (1862-1934), diretor do I.N.M. entre 1923 e 1930, que o crítico descreveu como sendo "o último dos professores, porque não professa coisa nenhuma neste mundo a não ser a arte de desmoralizar tudo quanto lhe passa pelas mãos"11.

Escrita em novembro de 1930, a matéria vem à tona no fim da gestão de Fertin, quando os debates e movimentos em torno de sua sucessão dominavam o ambiente musical do Rio de Janeiro. À época, o regulamento do Instituto previa que o seu diretor deveria ter a incumbência de reger a orquestra da casa nos concertos públicos (esta era uma dentre as muitas ressalvas que Guanabarino guardava em relação à atuação de Fertin, que não era regente). Ao saber que J. Octaviano era um dos nomes considerados para assumir o cargo diretivo, o crítico foi assertivo:

Agitam-se agora os pretendentes à substituição do diretor e fala-se até no professor Octaviano Gonçalves, por ser riograndense; mas esse professor tem contra si o facto de ter sido deposto, por incompetência, do cargo de regente da companhia lyrica brasileira que pretende estrear no próximo dia 13 de Novembro. O governo vae lutar com grandes dificuldades para

\footnotetext{
${ }^{11}$ Dentre as diversas atividades que exerceu, Fertin de Vasconcellos foi responsável por inaugurar editoras que publicaram centenas de obras de autores brasileiros, incluindo Ernesto Nazareth (1863-1934) e Chiquinha Gonzaga (1847-1935). Seu vínculo com as então denominadas "músicas de salão", "músicas regionais" ou "músicas características" também foi alvo da pena de Guanabarino: "Os admiradores do Sr. Fertin lucrarão, em todo o caso, o dispêndio com o projectado busto, em bronze, do diretor cuja demissão toda a gente espera. Mas não é só dentro do Instituto que se encontram admiradores do grande e célebre assobiador. Cá fora, no mundo capadócio, a sua popularidade é bem intensa, por causa do apoio que tiveram os tangedores de guitarras, violões, bandurras e cavaquinhos. Não fora elle e naquele templo não teriam ecoado as belíssimas produções regionaes que poeticamente se denominam: - Atirei o pau no gato - [...] e tantas outras maravilhas. Valha a verdade, no entanto, que nos obriga a reconhecer a victoria do regional e de tudo quanto é deles [referência à coluna e concurso $O$ que é nosso, lançado no ano anterior (1929) pelo jornal Correio da Manhã], sobre os vencidos de hoje, ídolos de outrora, condemnados ao esquecimento e até ao desprezo - Bach, Haydn, Mozart, Beethoven, Chopin, Wagner, Liszt e tantos outros" (JORNAL DO COMMERCIO, 1930, p. 2).
} 
encontrar um novo diretor que não seja um segundo Fertin com outro nome (JORNAL DO COMMERCIO, 1930, p. 2).

Contudo, sendo pianista e professor particular do instrumento, a pena ferina de Guanabarino se voltava de forma especial para os professores de teclas, caso específico de J. Octaviano. Após a morte de Henrique Oswald (1852-1931), em junho de 1931, Octaviano - que havia sido seu aluno, era um assíduo intérprete de suas obras e alguém de sua relação estreita - herdou os estudantes da classe de piano do antigo mestre. Ao comentar o caso, o crítico escancara o que pensava de J. Octaviano como pianista e professor.

\begin{abstract}
Realizou-se, por fim, a grande desgraça. O Sr. Octaviano, que é excelente chauffeur [motorista, uma referência ao fato de J. Octaviano ser detentor de carteira de habilitação para dirigir, habilidade ainda rara naquele momento], mas péssimo professor de piano, tomou conta da classe que estivera sob a direção do maestro Henrique Oswald [...]. Para figurar, pela primeira vez na sua vida, como guia de uma boa turma de pianistas, reuniu as antigas alumnas de Henrique Oswald e realizou um concerto no qual ficou evidenciada a decadência dessas infelizes alumnas. [...] Temos ainda outros commentarios sobre estes exames [audições de alunos realizadas no I.N.M. e que Guanabarino contestava a atribuição (ou não) de notas de distinção], mas ficarão para a próxima semana, no folhetim em que trataremos do concerto que Octaviano realizou no salão da Academia de Arte do Brasil, afim de estudarmos o que seja cabotinismo e a arte musical do bello Octaviano, numa atmosfera azul rodeada de flores, ostentando a sua importância igual a zero (JORNAL DO COMMERCIO, 1931a, p. 2).
\end{abstract}

Esta crítica foi publicada em 23 de dezembro de 1931, ano que fora um dos mais ativos de J. Octaviano, que se alternava entre as atividades de compositor, pianista, regente e professor, realizando ao menos 14 concertos distintos amplamente cobertos e, de forma geral, bastante elogiados pelo restante dos críticos em atividade no Rio de Janeiro (CORREIO DA MANHÃ, 1931: 5; O JORNAL, 1931a, p. 5), o que incluía os recitais nos quais organizava a apresentação de seus alunos. Eis um exemplo:

Realizou-se, hontem, no salão de concertos do Lyceu de Artes e Officios, pela primeira vez no Rio, a $1^{\text {a }}$ serie de audição completa dos 84 estudos de Cramer, executados a dois pianos, seguindo a edição revista e annotada por Arthur Napoleão, pelo professor J. Octaviano e seus alumnos, senhorita Elzi Abbaud e Werther Politano. [...] O concerto deixou a melhor das impressões no selecto auditorio do Lyceu (O JORNAL, 1931b, p. 11).

No fim daquele ano, o Correio da Manhã defendia que "incontestavelmente poucos artistas no nosso meio têm envolvido a actividade dynamica do illustre maestro J. Octaviano, não só como pianista, mas ainda como mestre e compositor" (1931a, p. 5) ${ }^{12}$.

\footnotetext{
${ }^{12}$ Somente naquele ano, Octaviano realizou ao menos três recitais de piano exclusivamente com repertório brasileiro (incluíndo uma homenagem a Henrique Oswald), outros dois com obras de autores canônicos das
} 
Para Guanabarino, entretanto, o músico não passava de um cabotino e usurpador.

Conforme prometera, o crítico dedicou a sua coluna da semana seguinte (30 de dezembro

de 1931) integralmente ao desafeto, esbugalhando as diferenças entre ambos e deixando

nítido que a questão extrapolava o âmbito artístico (tão pessoal que, em determinado

momento, utiliza o verbo "vingar-se" para qualificar a relação). A passagem é longa, mas

vale a pena transcrevê-la por ser um retrato cru de como as disputas práticas e simbólicas

em torno da música eram violentamente travadas.

O exame final da alumna Georgette Ramy provocou uma serie de factos que não podemos deixar cahir no olvido [esquecimento]. Quando essa artista, na opinião de Henrique Oswald, terminou a sua prova, a sala quasi em peso foi cumprimental-a, e também à Sra. Ramy, sua mãe e sua professora; mas desde que se conheceu a nota dada pela mesa examinadora o movimento foi de pasmo, para não dizer de indignação.

Essa indignação ecoou na imprensa. O grito de revolta não partiu somente das columnas desta folha: o Diario Carioca, pela penna da nossa illustre collega, Magdala da Gama Oliveira, que nessa folha exerce as funções de critico musical e com muito bom senso, bradou contra a injustiça que diríamos imoral porque o resultado obedeceu ao movimento baixo e reprovável de uma desforra procurando ferir ao mesmo tempo a alumna, que não reconheceu nem podia reconhecer em Octaviano Gonçalves um professor digno de sua arte, mas também a Sra. Ramy, que o contrariou por vezes, e ainda vingar-se do autor destas linhas porque não o tem na conta de professor de coisa nenhuma. Correu o risco de ser julgado pela opinião publica: mas esse senhor, cuja origem ninguém conhece não liga a menor importância ao meio musical nem à opinião da gente honrada. Julga-se acima de tudo e de todos, porque é, no Brasil, o único musico que tem carta de chauffeur!

A senhorinha Magdala da Gama Oliveira escreveu a respeito desse homem umas phrases que representam o ferro em brasa causticando a sua prosapia. Toda gente leu na sua chronica as seguintes palavras: 'O Instituto Nacional de Musica, com todo o apparato da sua organização, não póde fabricar artistas, porque o talento não se cria, plasma-se. O que o Instituto póde fazer - e quantas vezes já o fez! - é atrophiar a materia prima dos alumnos que lá entram em busca de ensinamentos, entregando-os às mãos sacrilegas de professores ineptos, que lá estão levados por pistolões políticos praticando os mais deslavados erros pedagogicos'.

Estas palavras não encerram uma indirecta a J. Octaviano Gonçalves: são, no contrario, uma allusão franca, decisiva, clara e justa contra esse professor de piano que no decurso da sua vida artística (?) ainda não conseguiu formar uma única alumna tocando, ao menos regularmente. Ao contrario, no concerto por elle organizado para apresentar as infelizes alumnas de Henrique Oswald e que passaram a receber as suas irrisorias lições, o auditorio ria-se e muita gente entristecia-se vendo como se estragam verdadeiros talentos e como póde um iconoclasta desmanchar com os pés o que fôra pacientemente construido pelo saber.

teclas (do barroco ao romantismo), estreou um repertório de canções brasileiras “características" adaptadas por ele para canto e orquestra, foi solista do concerto para piano de Henrique Oswald no Theatro Municipal, regente em seguidas apresentações orquestrais no Teatro Casino, além de organizar diversas apresentações de alunas (os) em espaços importantes e ser continuamente programado como compositor (inclusive com estreias no Theatro Municipal). 
Quando tivemos noticia do resultado de exama da senhorinha Georgette Ramy, o nosso primeiro ímpeto foi organizar um recital publico para a pianista Georgette Ramy executar o programma de seu exame recital dedicado ao Professor Octaviano Gonçalves e precedido de uma conferencia nossa tendo por thema - O Caracter.

Pois é esse professor, que não sabe ensinar e estraga os alumnos adiantados que lhe cahem nas garras, que vae ser nomeado lente cathedratrico do Instituto e substituir o grande mestre Henrique Oswald.

Reparem bem. Estamos em Dezembro de 1931, o concurso patacoada será realizado em Março de 1932 e nós, no alto destas columnas denunciamos desde já, ao Brasil inteiro, a immoral combinação existente de ser dada essa cadeira a J. Octaviano, e a outra, vaga pelo fallecimento do professor Alfredo Bevilacqua, doada ao Sr. Radamés Gnattali [que nunca chegou a ser professor do Instituto], que tem a seu favor duas grandes recommendações - ser riograndense e ter sido alumno do actual director, que o recommenda como repetidor para as suas alumnas, preparando assim mais um titulo para ser apreciado pela comissão examinadora e levado em conta do seu merecimento.

Mas o caso mais interessante na actualidade é ver como o pseudo professor de piano procura tapear o publico para justificar a sua nomeação em Março de 1932, e para preencher a cadeira que foi honrada pelo grande mestre Henrique Oswald.

Já dissemos por intermedio destas columnas que as infelizes alumnas do maestro Oswald perderam terreno desde que passaram a receber as sapientissimas lições de Octaviano Gonçalves. Podemos accrescentar que o auditorio reunido para ouvir aquellas senhorinhas ria-se, quasi seguidamente, diante do desastre que se transformava em ridiculo. Pela primeira vez reuniu-se um grupo de pianistas que passaram por alumnas de Octaviano: mas além de não terem sido alumnas do seu curso, ainda ha um facto bem caracteristico que realça as qualidades negativas desse professor que, pretendendo empoleirar-se na cathedra que foi de Henrique Oswald por meio de uma verdadeira doação, não apresentou a exama este anno, no Instituto, nenhuma alumna preparada por elle: ao contrario, obteve uma nota de distincção para uma alumna que fôra preparada pela professora Haydée Mor Meyl e que fez exames com o mesmissimo programma com o qual se apresentara ao concurso de admissão na qualidade de alumna da alludida professora! Quer dizer que durante o anno lectivo o pretenso professor de piano não preparou essa alumna para exhibir-se nem sequem em um simples estudo preparado sob a sua direcção!

Vamos interromper, por alguns momentos, o fio destes argumentos, para citar uma ocorrencia que, com certeza, encherá de indignação o animo de todos os admiradores de Henrique Oswald.

Um professor, livre docente [caso de J. Octaviano], gritou na secretaria do Instituto Nacional de Musica: - 'Vivo a fazer propaganda das composições desse velho idiota e no emtanto recusam-me as suas alumnas e estão enchendo o curso de um novato na casa!'

Está a prêmio esta charada infame.

Prosigamos.

Fomos ao concerto realizado por Octaviano Gonçalves no salão da Academia de Arte no Brasil, fundado pelo professor João Rocha.

Quando lá chegamos, sem convite, provocamos uma crise de nervos no concertista. A nossa presença ia entornar o caldo e desmanchar a serenidade daquelle acto que representava mais um reclame para engazopar o governo e justificar o plano da sua nomeação, em Março, para professor de piano no alludido estabelecimento de ensino.

Apreciem agora o que na giria theatral recebeu o nome de cabotinismo. A sala que comportava o auditorio estava profusamente illuminada: em frente uma outra, de construcção circular, completamente às escuras. Essa 
saleta é o logar em que se collocam os musicos, os declamadores e dansarinos. $\mathrm{O}$ piano de cauda está sobre um estrado com dois degraus e todo elle forrado com um panno escuro.

A nossa curiosidade bisbilhotou por esse recinto. Os degraus estavam recamados de petalas de rosas, e dois grandes ramos de flores completavam a ornamentação florida desse scenario.

Depois de uma boa meia hora de espera o recitalista veiu lá de dentro enfiado na sua casaca... ou a casaca enfiada nelle. Tomou posição, olympica, já se vê, e eis senão quando as claras luzes da sala do auditorio extinguem-se por completo, e a rotunda se illumina de bellissima e intensa côr azul!

Bello quadro, sim, senhor!

Sabe-se que Octaviano é um bicho muito feio, quasi um anthropoide com a habilidade de conservar-se a prumo.

Calculem, aquelles que o conhecem, o Octaviano a sorrir emquanto o publico applaude o Passaro azul, linda opereta pouco divulgada nesta Capital sob o titulo de Arara!

Elle sorria: e muita gente atafulhava o lença na boca para não estrondear a gargalhadas.

E começou a exhibição de Octaviano - concertista.

Primeiro numero - Duas sonatas de Scarlatti. Qualquer alumno do quinto anno do Instituto sabe que o professor errou, apesar do seu titulo de compositor, tão apregoado pelo Prof. Raymundo da Silva. O que elle executou foi a pastoral de uma sonata, transcripção de Tausig; mas apesar de ser uma peçazinha do $6^{\circ}$ anno, o celebre pianista, compositor, harmonista, fuguista, contrapontista e chauffeur, esbarrou tres vezes, e na Sonata os esbarros subiram a cinco. Cinco e tres - igual a oito-oito esbarros logo de começo!

Em seguido o Nocturno op. 9 n. 2 de Chopin, o mais facil dos nocturnos desse autor, tanto que esta classificado no $5^{\circ}$ anno: quanto à interpretação - realejo ou pianola, modelo primitivo. Depois desse nocturno, executado sem arte, sem sentimento e sem expressão, seguiu-se uma peça que não havia meio de atinar qual fosse. Conseguimos, afinal, um programma e vimos então que o grande pianista estava executando a Mazurca op. $24 \mathrm{n}$. 1, do $6^{\circ}$ anno, e logo após o Estudo op. 25, n. 1, o mais fácil de todos, accessível a uma criança do $4^{\circ}$ anno. Mas era preciso enfeitar o programmma com alguma coisa de Chopin...

Veio então a Rhapsodia hungara, n. 13, de Lizst, e o pianista poz em pratica a sua intelligente escola do - vae ou racha: mas não foi nem rachou apenas ensuderceu o auditorio com o pedal constante.

Em homenagem aos autores brasileiros Octaviano executou o Scherzetto, de Miguez: e mais o Nocturno, de Alberto Nepomuceno que elle (Octaviano) teve a honra de executar há doze annos passados, para ser admirado pela pianista Lucia Branco.

A segunda parte do programma era J. Octaviano - Compositor.

Admirem agora a o trabalho herculeo desse genio do professorado. Em Novembro deste anno e durante tres dias fez executar em publico os 84 Estudos de Cramer, 'executados em dois pianos, segundo a edição revista e annotada por Arthur Napoleão'.

Tudo isto está errado. A edição à qual se refere o celebre professor é aquella para a qual Arthur Napoleão escreveu a parte de um segundo piano, imitando o que já fôra feito por Henselt [Adolf von Henselt (1814-1889), pianista e compositor alemão].

J. Octaviano declarou nos programmas que essas execuções appareciam 'pela primeira vez no Rio de Janeiro'.

Pela primeira vez foi a estopada dos 14 estudos, e sabe Deus como! Mas convem lembrar ao enorme professor de piano que Arthur Napoleão quando commemorou o seu primeiro concerto nesta capital, em 1837, 
executou a Somnambula de Thalberg [Sigismond Thalberg (1812-1871), compositor e pianista suíço/austríaco] peça por elle incluida no primeiro concerto: e na qualidade de autor de um segundo piano para os Estudos de Cramer, executou, ali no Municipal, varios numeros desses estudos com Guiomar Novaes, sem amollar o publico e sem estropiar os estudos.

J. Octaviano não perde occassião para impingir-se ao publico, como vamos demonstrar.

No concerto realizado no dia 19 , quando terminada a execução das suas estopadas, surgiu elle no palco, sempre illuminado pelas lampadas azues e realizou mais uma conferencia, a pedido dos seus admiradores e das suas admiradoras, para que elle Octaviano Gonçalves dissesse quem era elle! O thema, pois, era - "Eu, isto é, Elle". E fez a sua apologia, atirou às nuvens mostrou que no Brasil - Elle, só elle, era notavel nas artes e bello na plastica. O publico ria e elle enchia-se de garbo para dizer emphaticamente: - O artista não se faz - nasce!

(Sensação no auditorio).

Ó Sr. Octaviano!

O macaco tambem nasce e no entanto não é artista.

Às vezes, quando é ensinado, toca piano, o que não é milagre, tanto que vive por ahi um tocador de piano que toda a gente sabe que é o Zé Macaco. Além disso o grande poeta portuguez viu uma macaca ser caixeira de uma venda, e uma perda que fazia renda - ou vice-versa, dando tudo na mesma. Para terminar daremos um conselho a J. Octaviano. Na sua qualidade de admirador de Henrique Oswald abra um inquerito para saber e divulgar quem foi o cretino que na secretaria do Instituto chamou o grande mestre de - Velho Idiota. Oscar Guanabarino (JORNAL DO COMMERCIO, 1931b, p. 2).

Os questionamentos são de toda ordem: morais, éticos, artísticos, institucionais, mas sobretudo pessoais, já que ninguém ridiculariza a aparência de alguém ("bicho muito feio”) ou o chama indiretamente de macaco em nome de uma suposta retidão artística. Ainda assim, no bojo deste intenso bombardeio, cumpre destacar dois aspectos mais diretamente relacionados ao fio condutor deste estudo:

1) Guanabarino tem a dimensão precisa de como os seus movimentos como crítico poderiam interferir direta ou indiretamente na organização do tabuleiro. E aqui reconhecemos essa atuação em um sentido mais amplo, não somente no ato de escrever e publicar suas impressões, mas também quando vai a um concerto reconhecendo que sua presença física poderia provocar uma "uma crise de nervos no concertista". É consciente e cioso do papel que ocupava e exercia esse poder em sua plenitude, inclusive como forma de preencher o vácuo dos eventuais espaços que lhe eram negados dentro das lutas do campo. O Instituto Nacional de Música não foi um de seus temas mais recorrentes por acaso ou somente porque, no embate com a instituição, reverberava a sua autoproclamada condição de paladino da moral e dos bons modos artísticos (que o diga a descrição da sala no evento protagonizado por J. Octaviano). Sua ira - muitas vezes questionando situações legítimas - era irremediavelmente proporcional ao não reconhecimento simbólico que lhe 
oferecia o Instituto. Antes de tudo, tratava-se de uma disputa. E este parece um dos aspectos que não podemos perder de vista para compor um quadro menos comprometido sobre as instituições, as práticas e os personagens envolvidos: os seus interesses nunca foram isentos, ao menos completamente.

2) O que fundamentalmente interessa a Oscar Guanabarino e a J. Octaviano é a disputa pela cátedra de piano de Henrique Oswald, falecido em 9 de junho de 1931. Ressalte-se que o crítico não a requeria propriamente para si, mas para que ela tivesse a chance de ser ocupada por alguém que melhor representasse o seu ideário pianístico (há muito apartado de Octaviano). Para tanto, jogou contra o músico com todas as suas armas, chegando ao ponto de insinuar que o pianista teria sido o "cretino" que violou a memória de seu antigo mestre ao chamá-lo de "velho idiota" na secretaria do Instituto. Não é fortuito que o crítico tenha escolhido justamente esta acusação para finalizar uma coluna integralmente dedicada a desqualificar J. Octaviano. Este, por sua vez, articulava-se, organizava ou protagonizava concertos diversos, botava as suas alunas e alunos em cena (ainda que não fossem preparados por ele), promovendo-se como podia para mostrar que estava à altura do cargo. Enfim, faltavam três meses para que o destino da cátedra fosse decidido e ambos apostavam alto, botando à mesa as suas melhores fichas.

De antemão, Guanabarino deslegitimou o "concurso patacoada", afirmando que a vaga de Henrique Oswald já estava destinada a J. Octaviano. Com isso, o crítico se jactava a condição de quem só poderia estar certo: se o pianista ganhasse, mérito do tapetão; se perdesse, teria sido porque a denúncia antecipada permitiu a realização de um certame isento. Aliás, embora a cátedra de Oswald fosse a joia mais preciosa por seu valor simbólico e histórico, Guanabarino também não se furtou a condenar a disputa de uma segunda vaga, segundo ele já prometida a Radamés Gnattali (1906-1988) pelo então diretor do Instituto, Guilherme Fontainha (1887-1970). Curiosamente, Radamés nunca chegou a ser efetivado como professor da casa, um indício de que as supostas cartas marcadas podiam ser embaralhadas. O jogo tinha (e tem) as suas aberturas, a depender dos movimentos dos envolvidos.

Guanabarino sabia disso melhor que ninguém. Por isso mesmo, no início do ano seguinte, continuou desqualificando a inscrição e a atuação de J. Octaviano no embate pelo posto de catedrático de piano, retorquindo notas positivas publicadas sobre o músico 
em outros jornais (como o Jornal do Brasil), deslegitimando a defesa pública de sua tese sobre Chopin, reiterando que o pianista havia estragado as alunas de Henrique Oswald e Haydée Mor Meyl, acusando-o de forjar homenagens e confetes para si, além de lhe imprimir mais uma série de apelidos jocosos, dentre os quais o de "urubu malandro" cujas penas de pavão já haviam sido arrancadas: "É o typo de convencido que não perde vaga para engazopar o público, sem receio, sem medo de ser desmascarado" (JORNAL DO COMMERCIO, 1932a, p. 2). O motor de sua metralhadora continuava girando em torno das disputas pelas vagas de professor catedrático do Instituto (uma categoria mais distinta se comparada ao "livre docente"):

[...] durante quinze annos de atividade, só conseguiu, até hoje, uma alumna (uma só) laureada com um segundo premio, quando ali, no Instituto, andam à matroca as medalhas de ouro.

E depois desses desastres, cujo histórico daria um livro cheio de interesses, sabe-se que Jota Octaviano pretende o logar de cathedratico de piano no Instituto!

Um outro pretendente a uma das cathedras daquelle estabelecimento é o Sr. Villa-Lobos; mas esse não quer submeter-se a concurso; quer ser nomeado professor de canto choral porque fez os músicos da banda de Bombeiros cantar o seu samba em côro (JORNAL DO COMMERCIO, 1932a, p. 2).

A passagem inclui Villa-Lobos não por acaso, mas como demonstração de que, antes da avaliação dos méritos musicais, o que está em jogo é a defesa de uma determinada visão artística que, de quaisquer dos lados, deseja se impor sobre a outra como hegemônica. $\mathrm{O}$ crítico guardava verdadeira ojeriza em relação à incorporação da então chamada "música característica" (vinculada às tradições populares, folclóricas, indígenas) à música de concerto tradicional, execrando a ideia de que J. Octaviano ou Villa-Lobos pudessem ser professores do Instituto Nacional de Música - o estabelecimento oficial de ensino musical do país naquele momento - não somente por desacreditar os critérios de seleção dos concursos ou as capacidades profissionais de ambos, mas sobretudo porque eles não representavam o ideário estético encarnado pelo crítico e os partidários de seu grupo ${ }^{13}$.

\footnotetext{
13 Algo particularmente demonstrado na sequência do texto, quando Heitor Villa-Lobos é classificado como sambeiro, envernizador de músicas indígenas e alguém que não dominava o métier tradicional resguardado por Guanabarino: "Villa-Lobos, artista consagrado em Paris, onde também foram consagrados os 'Oito Batutas', não quer entrar para o Instituto, como professor, por meio de concurso, porque gato escaldado d'agua fria tem medo, proverbio que atracado ao lombo do illustre envernisador das poesias dos tapuias e chavantes, e que, senhor de uma lenda dos tupyniquins, está escrevendo um poema tupyniquinho, precisa e exige (o tal proverbio do gato) uma explicação. De facto, o grande compositor quiz, de uma feita, ser professor de musica, de princípios elementares da arte musical, e inscreveu-se para concorrer a uma das cadeiras dessa maioria instituida pela Municipalidade. Abram os olhos e os ouvidos, caríssimos leitores!
} 
A questão em torno dos "grupos" é tão decisiva que os termos utilizados para representá-los são justamente os que denotam filiação em linhas hereditárias. Não é à toa que Guanabarino chamava as jovens que estudavam com suas alunas e ex-alunas de "netinhas", ou seja, as filhas de suas filhas. Eram suas crias, portanto. Naturalmente, as habituais análises duras ganhavam um contorno bem mais ameno quando o crítico tratava daquelas que pertenciam à sua linhagem, inclusive sendo capaz de invocar o amor para descrevê-las.

\begin{abstract}
Em dias de Novembro do anno passado, conforme noticiamos, ouvimos as nossas netinhas, alumnas da professora Alzira Fonseca, poucos dias antes de terminar o anno ouvimos outro grupo de netinhos, discípulos da professora Lisette de Oliveira, todos mui bem guiados, mas destacando-se os três últimos [...].

Vao nestas ultimas linhas um reclame a professora Lisette de Oliveira: más amor com amor se paga, e essa alumna que tanto se distinguiu quando sob a direção de Arthur Napoleão declarou nos programas da sua festa: 'Lisette de Oliveira, medalha de ouro do Instituto Nacional de Musica e com o curso de aperfeiçoamento do maestro Oscar Guanabarino'.

Hoje no salão Nicolas, teremos uma audição das alumnas da professora Emilia Amaral Silva e brevemente a das alumnas da professora Celeste Mascarenhas, o que representará mais duas turmas de netinhas nossas (JORNAL DO COMMERCIO, 1932b, p. 2).
\end{abstract}

Nem de longe parece o personagem que, na mesma coluna, fora implacável com Villa-Lobos e J. Octaviano. À propósito, logo na sequência destes momentos de ternura, Guanabarino defende a ideia de que o Instituto, antes de qualquer nomeação definitiva em seu quadro de professores, deveria nomear um "advogado do diabo" para perscrutar "a vida do preconizado e descobrir-lhe algum vício ou prática de qualquer acto que o torne incompatível com a sua elevação ao altar" ${ }^{14}$ (JORNAL DO COMMERCIO, 1932b, p. 2). Ora, a quem se referia quando invocava a presença de um "advogado do diabo"?

Mas isso parece apenas pano de fundo para a questão principal, que circundava em torno de quem, naquele momento, detinha o poder de assinar a filiação das principais

\footnotetext{
Villa Lobos nesse concurso - foi reprovado! É verdade que o illustre sambeiro tem uma justificação. Os examinadores não o deixaram esticar um discurso, e atazanavam o homenzinho com perguntas da artinha, coisas a que elle não liga a menor importância, como, por exemplo, a composição dos accordes. Dizem até que o grande mestre não conhecia a escala geral, coisinha atôa que as crianças aprendem no Instituto". (JORNAL DO COMMERCIO, 1932a, p. 2).

${ }^{14} \mathrm{O}$ recado era explicitamente dirigido a J. Octaviano, a quem ele imputava a fama de ser rude com as alunas mulheres: "Assim também, resolvida a nomeação de um professor, que vão lidar com meninas e senhorinhas, devia-se nomear uma commissão de inquérito para indagar da origem do professor indicado, dos seus costumes, da sua educação, dos seus antecedentes como professor". Segundo o crítico, a intenção era evitar um "malcriado, de origem baixa e não limado pela educação, impaciente e grosseiro (que bela carapuça!)." (JORNAL DO COMMERCIO, 1932b, p. 2).
} 
promessas cariocas do instrumento. Em outras palavras: quem poderia ensiná-las? Quando o crítico se dirige à sua ex-aluna Lisette de Oliveira afirmando que o "amor se paga com amor", o faz porque ela havia impresso no programa de concerto das suas estudantes o reconhecimento de que fizera o "curso de aperfeiçoamento do maestro Oscar Guanabarino”. Antes de tudo, tratava-se de reivindicar uma assinatura: clamar para si a melhor escola de formação pianística do Rio de Janeiro. Neste sentido, Guanabarino não se tornou persona non grata do Instituto somente por birras infantis (de adultos), mas porque historicamente a instituição não the reconheceu a posição simbólica que julgava merecer (e vice-versa). Neste jogo, ambos os lados operavam tentativas de silenciar, apagar ou deslegitimar os seus contrários.

Isto parece explicar porque o cerne da confrontação com J. Octaviano quase sempre foi pautado por questões de origem cultural, filiação artística, escola técnica/estética/estilística ou relativas à eventual falta de méritos para ocupar a cátedra de piano no Instituto Nacional de Música. Em suma, o propósito era o de esvaziar o poder da assinatura de um de seus concorrentes mais ilustres.

\footnotetext{
Dias depois líamos em um dos diários desta Capital a seguinte nota: - 'Com a nota de distincção passou do $6^{\circ}$ para o $7^{\circ}$ anno de piano, do Instituto Nacional de Musica, a estudiosa alumna senhorinha Hilda Reis [...] Foi seu professor o conhecido maestro J. Octaviano'.

Nota necessária. Essa alumna foi preparada pela professora Haydée Mor Meyl e fez exame com o mesmo programma do concurso à admissão. Arrancadas as pennas do pavão o que apparece não é a gralha da fabula, mas sim um urubu malandro! ${ }^{15}$ (JORNAL DO COMMERCIO, 1932b, p. 2).
}

\footnotetext{
${ }^{15}$ Esta associação da imagem de J. Octaviano a um pavão foi também utilizada por Ondina Ribeiro Dantas, a D’or, importante crítica musical do Rio de Janeiro e a responsável por assinar a coluna "Música Commentarios", no Diário de Notícias, jornal carioca de grande circulação e que pertencia a seu marido, Orlando Dantas (ela chegou a assumir a direção da publicação depois de ficar viúva). D'or costumeiramente elogiava os concertos e composições de J. Octaviano, mas fez uma dura crítica à publicidade que o músico vinha fazendo em torno de si, especialmente no que diz respeito à apresentação pública de suas alunasprodígios (uma verdadeira febre que tomou conta do Rio de Janeiro a partir das primeiras décadas do século $\mathrm{XX)}$. Na ocasião em que chamou o músico de pavão, tratava do concerto da pequena pianista portuguesa Maria Quintanilha, de 08 anos, que há três meses estudava com J. Octaviano para fazer o seu debut oficial no Rio de Janeiro: "É interessante observar como a volupia de publicidade adormecia por completo certos espiritos, emmaranhando-os n'uma verdadeira tela de tristes e espectaculares reclames trazidos a publico pelo proprio interessado. O professor J. Octaviano, de quem reconhecemos o valor, está agora sob a influencia dessa molestia que campeia em todo o globo, em caracter permanente, mas que não attinge a toda a gente, graças a Deus. [...] Mas, afinal, porque tanto barulho? É se agregar sem cerimonia, às glorias alheias, enfeitando-se com pennas de pavão. D'OR” (DIÁRIO DE NOTÍCIAS, 1938b, p. 9).
} 
Embora encontrassem em Guanabarino e eventualmente em outros articulistas um contrapeso contundente, de modo geral, as composições e concertos de J. Octaviano e de suas alunas e alunos seguiam continuamente aclamados pela maioria dos outros críticos e jornais cariocas de grande circulação, bem como pairava sobre ele uma avaliação positiva de seu trabalho pedagógico. Quando Luiz Heitor Côrrea de Azevedo publica 150 Anos de Música no Brasil, afirma que "Como professor, J. Otaviano tem boa reputação e é autor de compêndios de Teoria e Análise Musical (AZEVEDO, 2016 [1956], p. 163).

$\mathrm{Na}$ imprensa carioca, esta imagem de professor zeloso e competente foi seguidamente reiterada até 1962, ano de falecimento de J. Octaviano. Fiquemos apenas com alguns dos muitos exemplos ${ }^{16}$ retirados das duas décadas (1920 e 1930) em que o músico recebeu as críticas mais ferozes de Guanabarino: “É hoje, finalmente, que se realiza o recital de piano da talentosa senhorita Maria José Pinto, alumna do Instituto Nacional de Música, onde tem feito um curso brilhante como alumna do professor J. Octaviano" (O PAIZ, 1922b, p. 2); “Justo é salientar o nome do professor J. Octaviano como uma das forças animadoras da mocidade artística. (DIÁRIO CARIOCA, 1931b, p. $3)$ ".

\begin{abstract}
Esse concerto foi, realmente, um delicioso serão de arte, que aquella distincta alumna de piano [Zilah de Moura Britto], do professor J. Octaviano, reaffirmando a sua vocação já tantas vezes assignalada, revelou notavel aproveitamento nos seus estudos, quer em technica, quer em fidelidade interpretativa dos mais difficeis classicos (GAZETA DE NOTÍCIAS, 1926e, p. 3).

O professor J. Octaviano foi muito cumprimentado pelo exito que os seus discipulos alcançaram, cumprimentos justos por todos os motivos, principalmente pela prova exuberante que acabava de apresentar, deliciando a platéa que enchia literalmente o salão, com quatro alumnos ricos de talento [Werther Politano, Elzi Abboud, Luba Neiberger e Esther Neigerger] e de optima orientação musical Magdala da Gama Oliveira (DIÁRIO CARIOCA, 1931a, p. 6).

Hontem á tarde, o salão de musica de Camera, do I. N. de Musica, esteve repleto de profissionais e amadores da arte clássica dos sons, levados naturalmente pelas credenciaes do prof. J. Octaviano, a quem com justiça, consideram, entre os jovens artistas músicos brasileiros, o mais completo theorica e technicamente como pianista e compositor da nova geração [...]. 'A Batalha' e A ESQUERDA felicitam o maestro Octaviano e seus discípulos, como estímulo para a arte musical no Brasil. Dr. VICTOR PEREIRA (A ESQUERDA, 1931, p. 6).
\end{abstract}

\footnotetext{
${ }^{16}$ Sobre a atividade professoral de J. Octaviano, os recortes jornalísticos que levantamos entre 1918, data do primeiro, e 1962, data do último, somam 107 páginas do programa de textos Word.
} 
Muitas vezes, tais matérias eram ainda acompanhadas por manchetes garrafais e/ou fotos cheias de pompa e circunstância, o que deveria irritar profundamente Guanabarino:

Figura 1 - Recital de alunas de J. Octaviano.

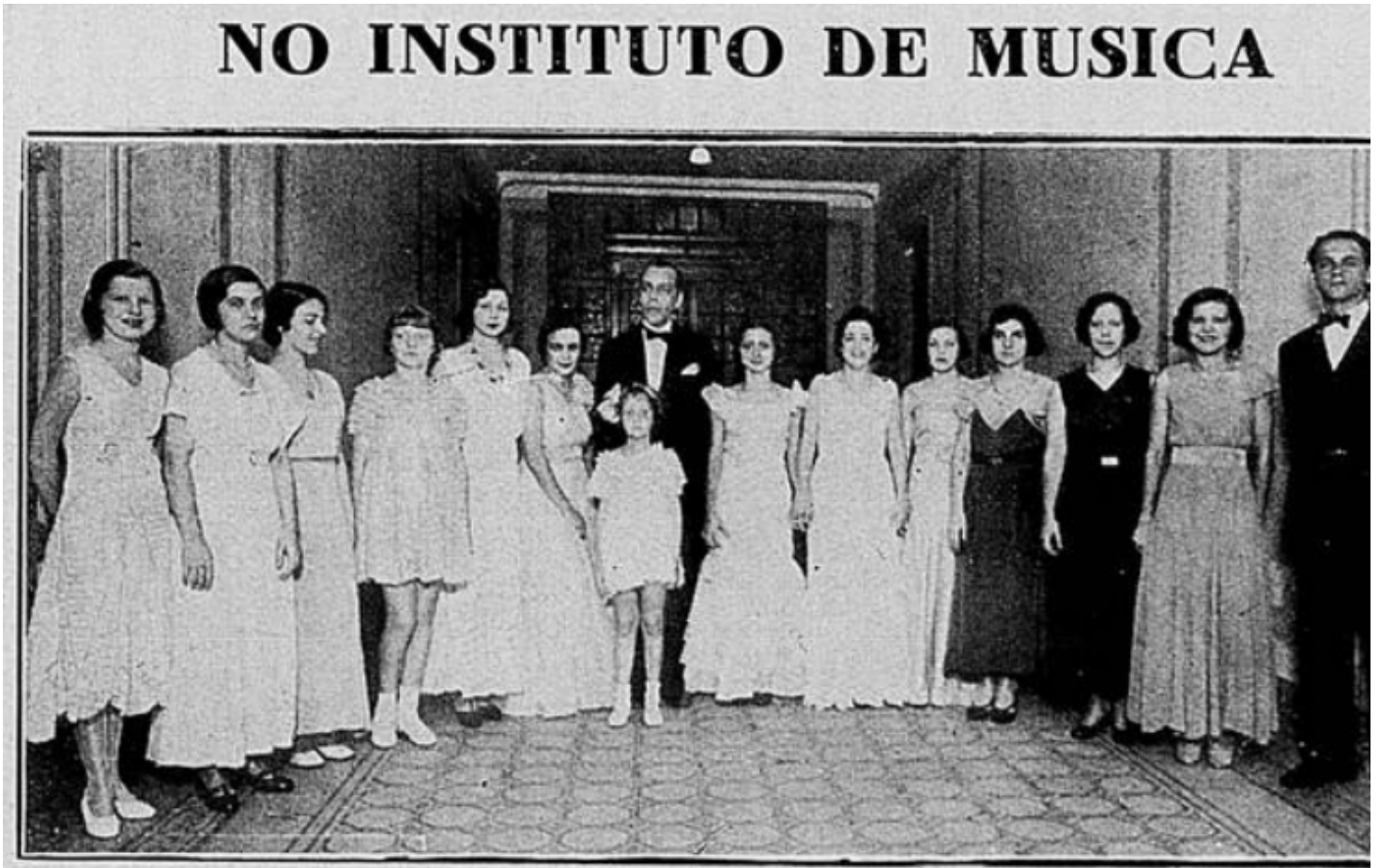

Audição das alumnas do professor J. Octaviano no Instituto Nacional de Musica. Fonte: REVISTA DA SEMANA, 1932, p. 24.

Figuras 2 e 3

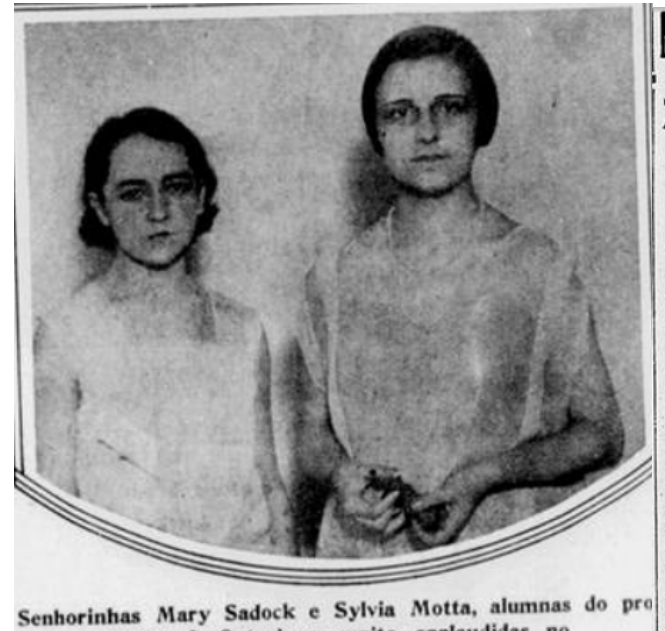
fessor J. Octaviano, muito applaudidas no concerto que realizaram.

Fonte: PARA TODOS, 1926, p. 33.

\section{No Instínto Nac onal de Masict} A AUDIČ̃O DE ALUMNOS DO MAESTRO J. OCTA.

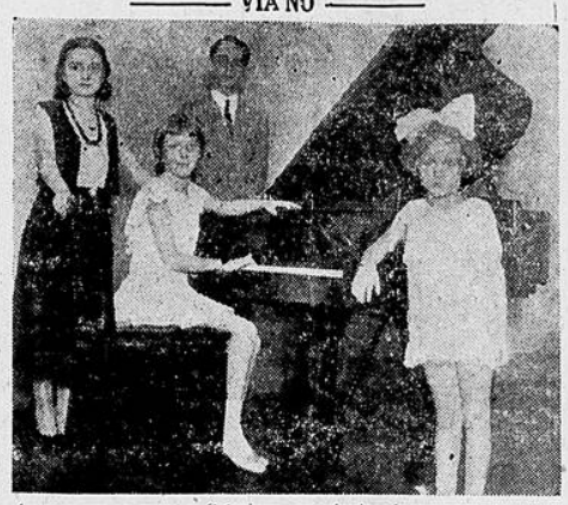

macosio Octaviano crcentantes do

Fonte: A ESQUERDA, 1931, p. 6. 
Figura 4 - "Realizou-se, hontem, no salão Leopoldo Miguez, do Instituto Nacional de Música, a audição das alumnas do acatado professor J. Octaviano. O programma teve cabal desempenho e, à proporção que se succediam os numeros de musica, eram as alumnas vibrantemente applaudidas pela assistencia".

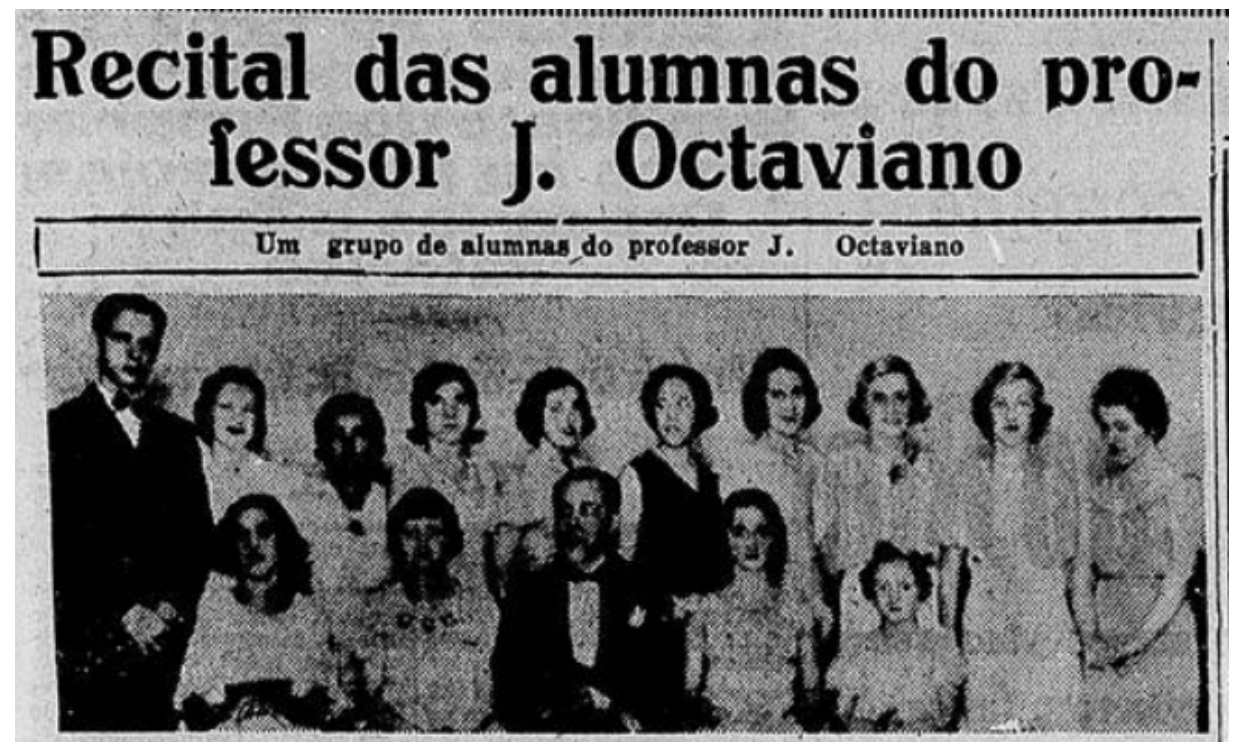

Fonte: DIÁRIO DE NOTÍCIAS, 1933, p. 7.

Figura 5 - "O programma e o desempenho agradaram a todos que assistiram o recital, tendo sido as jovens futuras artistas muito applaudidas, assim como o professor J. Octaviano".

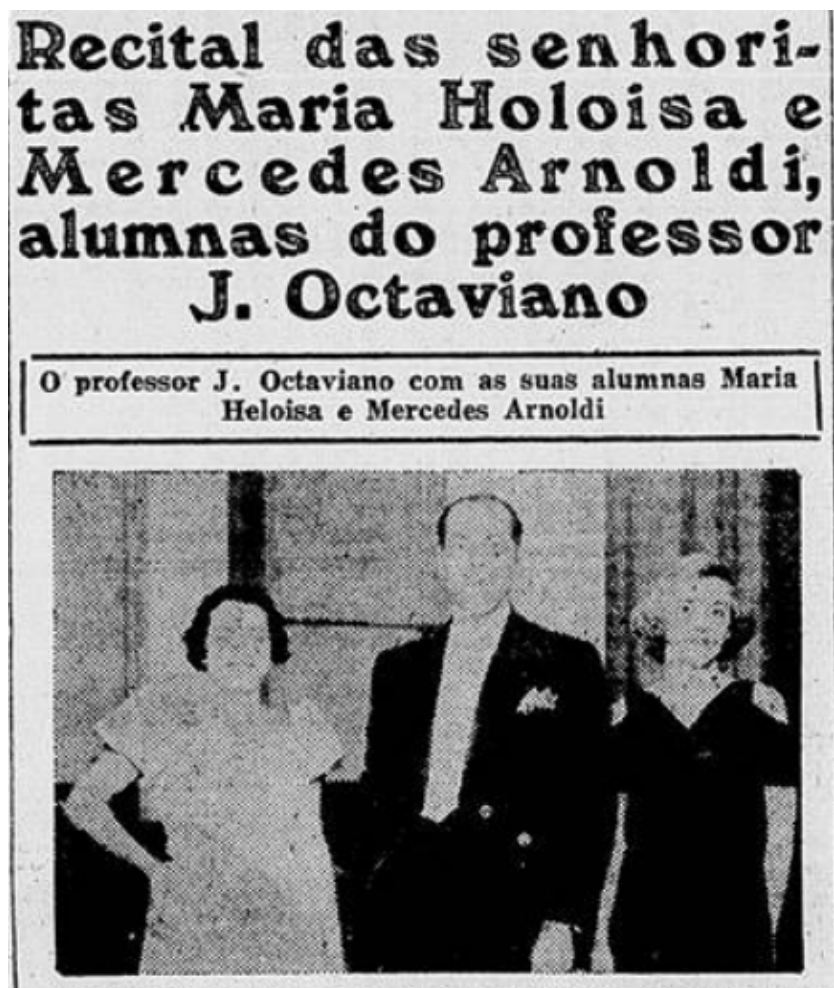

Fonte: DIÁRIO DE NOTÍCIAS, 1933, p. 7. 
Pouco importava. Em relação a J. Octaviano, Guanabarino não negociou qualquer trégua ao longo das duas últimas décadas de sua vida, convertendo qualquer brecha possível em oportunidade para voltar a deslegitimar a sua condição de compositor, pianista ou professor. No início de 1932, por exemplo, respinga no professor "Zé Octaviano" a desqualificação que o crítico mais uma vez incensa sobre a música de VillaLobos.

\begin{abstract}
- Os elementos principais da música são: melodia, harmonia e rythmo. A música de Villa-Lobos não tem melodia, não apresenta harmonia e não possue rythmo, de onde concluímos que não é música, não é arte, não é nada, a não ser uma salada de sons intragáveis.

Às barulhadas insupportáveis dos Kunkunkuns e dos kinkinkins preferimos a simplicidade de uma melodia de Stephen Heller [(1813-1888), pianista e compositor húngaro de traços românticos] executada por uma criança de talento e que tenha tido a felicidade de não cahir nas mãos do celebre professor Zé Octaviano, o estragador das alumnas de Henrique Oswald (JORNAL DO COMMERCIO, 1932b, p. 2).
\end{abstract}

Mais uma vez, a repulsa a escolas estilísticas diversas da que idealizava se impõe na leitura ácida que Guanabarino faz de Villa-Lobos. Ademais, o recorrente propósito de esvaziar a assinatura de J. Octaviano como professor permaneceu inabalável ao longo de 1932. Em sua última coluna daquele ano, reitera que as pianistas ensinadas pelo desafeto andavam para trás e que "toda a gente" o encarava apenas como um bibliotecário, alusão ao período em que o músico desempenhou esta função no Instituto, segundo o crítico, com a incompetência digna de um "macaco em loja de louça"17 (JORNAL DO COMMERCIO, 1932c, p. 2).

Nesta mesma crônica, Guanabarino chama a atenção para um fato que teria sérios desdobramentos: "O Sr. Octaviano Gonçalves tem experimentado professar várias disciplinas no Instituto; mas ninguém o procura para com elle estudar harmonia, nem contraponto, nem fuga, nem composição, conforme os seus annuncios" (JORNAL DO

\footnotetext{
17 “É da gente cahir das nuvens! É verdade que na arte musical isso de cahir das nuvens é coisa muito facil e até vulgar. Conosco deu-se isso há dias, lendo nos jornaes a noticia de um recital de piano que se realizaria no Instituto. A recitalista, como reclame, declarou ter sido alumna do nosso grande mestre Henrique Oswald, ter estudado, depois, com Philipp, em Paris, e terminado aqui o seu curso com o professor Octaviano Gonçalves! A progressão obedeceu à lei inversa: subiu, subiu e cahiu das nuvens! O Sr. Octaviano Gonçalves nunca apresentou nenhuma alumna apreciável que tivesse concluído os seus estudos com elle, a não ser as da turma do maestro Henrique Oswald, e isso mesmo notando-se que algumas dellas andaram para traz, desaprendendo. Era natural que isso se desse. O Sr. Octaviano Gonçalves tem experimentado professar varias disciplinas no Instituto; mas ninguém o procura para com elle estudar harmonia, nem contraponto, nem fuga, nem composição, conforme os seus annuncios. É que toda a gente o encara como bibliothecario, que o foi, no Instituto, cargo que deixou porque não tinha embocadura para aquella gaita. [...] Foi o mesmo que um macaco em loja de louça!" (JORNAL DO COMMERCIO, 1932c, p. 2).
} 
COMMERCIO, 1932c, p. 2). Era o prenúncio dos duros embates que estavam por vir, no ano de 1934, em torno da disputa por outra cadeira de professor, desta vez de contraponto e fuga.

\begin{abstract}
Vê-se, por ahi, a guerra que o diretor do Instituto [Guilherme Fontainha] move aos livre-docentes, tanto que usou de um restinho da sua influencia perante o Conselho Técnico Administrativo para alijar da cadeira de contraponto o illustre professor Paulo Silva e encaixar naquelle cargo o Sr. Octaviano Gonçalves, provavelmente com o intuito de amansar as furias desse seu colega, que o está processando por crime de injurias e diffamação, visto ter repetido em sessão do Conselho tudo quanto noticiaram os jornaes desta capital a respeito do Sr. Octaviano.

A consequencia dessa modificação é a parede pelas alumnas do curso de contra-ponto exercido pelo professor Paulo Silva. Allegam elas que o Sr. Paulo Silva conhece a fundo a matéria que professa e que é autor de um magnifico compendio, ao passo que o Sr. Octaviano Gonçalves apenas conhece por alto aquella matéria - por alto ou de ouvido.

Vê-se que no Instituto continua o descalabro influindo na desmoralização do ensino e na derrota na Reforma. Oscar Guanabarino (JORNAL DO COMMERCIO, 1934b, p. 2).
\end{abstract}

$\mathrm{Na}$ "guerra", para usar o termo de Guanabarino, fica explícito como os embates se travavam em vários níveis e incluíam personagens diversos. Os grupos se dividiam dentro e fora do Instituto ${ }^{18}$ e cada um deles tratava de espalhar e defender as suas narrativas através das páginas da imprensa. De fato, houve uma enorme polêmica em torno da disputa pela cadeira de contraponto e fuga, o que incluiu interpelações judiciais, abertura de processos administrativos, acusações de assédio, intervenção de alunas e pais, além de seguidas matérias com réplicas e tréplicas. Nas palavras do Diário Carioca, uma "agitação" que moveu febrilmente os partidários de ambos os grupos.

Figura 6 - Manchete sobre a polêmica envolvendo a disputa pela cadeira de contraponto e fuga do Instituto Nacional de Música

\title{
0 Instituto Nacional de Musica novamente em foco Uma agitação entro professores e alumnos
}

Fonte: DIÁRIO CARIOCA 1934a, p. 3.

\footnotetext{
${ }^{18}$ Comentando outro tema, o próprio Guanabarino insinua que as guerras dentro do Instituto eram contínuas e ferrenhas: "Os [professores] restantes não têm tempo para isso, porque vivem em continua guerra. Os cathedraticos, por exemplo, capitaneados pelo director, desejam banir os livre docentes e planejam, ao mesmo tempo augmento de vencimentos por meio de equiparação aos da Escola de Ouro Preto - esse pouco; mas não se lembram das coadjuvantes que são miseravelmente retribuídas e que trabalham tanto ou mais que os cathedraticos" (JORNAL DO COMMERCIO, 1934b, p. 2).
} 
Neste caso, embora tenha conquistado a cadeira, refutado as acusações nos jornais e conquistado a absolvição em todos os processos administrativos que respondeu nas instâncias do Instituto (e que se prolongaram ao longo de 1934), J. Octaviano foi o mais ferido na guerra, sofrendo um abalo irremediável em sua reputação. As acusações, sobretudo as éticas, eram graves demais e os desdobramentos do imbróglio o levaram a um patamar de desconfiança moral que extrapolava as discussões técnicas e/ou institucionais concernentes ao exercício do cargo.

No centro delas, estava a acusação de assédio a uma de suas alunas, menor de idade, escândalo que provocou uma reação em cadeia envolvendo a imprensa, a instituição, as alunas e os seus pais. Ao retratar o caso, o Diário Carioca reafirma que, como pianista, "todos aplaudimos" J. Octaviano Gonçalves, mas pontua que não poderia atestar a mesma competência na disciplina de contraponto e fuga. Todavia, o seu verdadeiro impedimento seria de outra natureza: "Quanto à moral é um verdadeiro desastre, pois já se tornou conhecido como D. Juan perigoso. Nesse terreno, sim, é que talvez tenha pratica de fuga...." (DIÁRIO CARIOCA, 1934a, p. 3). Depois de espalhada, a má fama isolou J. Octaviano, em uma reverberação da suspeição impingida por críticos, colegas, estudantes e seus responsáveis.

UM PROFESSOR ÀS MOSCAS. Emquanto, porém, não houver uma providencia honesta para o caso, o sr. Octaviano que vá lecionando Contraponto e Fuga às moscas, porque nós não iremos às suas aulas. Não iremos, nem nossos paes consentiriam que fossêmos, porque a fama do 'homem' exige as maiores precauções...'

Estava satisfeita a nossa curiosidade. Já era tarde para maiores indagações. Ao sair, deixamos a estudantada a concertar os planos de defesa.

CONCLUSÕES. O caso do professor João Octaviano Gonçalves, encerra escândalos de toda ordem, dahi o movimento que vem sendo feito contra a sua nomeação.

No Conselho technico a repulsa é das maiores, os seus membros combatem a sua investidura por dois pontos: um por existir a grave accusação de ter, o referido professor maculado uma sua alumna, sendo o facto comunicado a policia, e em torno do caso sido feito grande escandalo publico e ainda por não ter elle direito [à cadeira] de accordo com o regulamento em vigor. Por outro lado os paes dos alumnos, conhecedores do acontecido, tem receio de que suas filhas recebam ensinamentos de tal mestre, dahi a repulsa geral que existe no Instituto Nacional de Musica.

O caso como se vê promete pannos para mangas (DIÁRIO CARIOCA, 1934a, p. 3)

O mencionado plano de defesa da estudantada logo se converteu em ação prática: o diretório acadêmico do Instituto Nacional de Música enviou um longo ofício ao presidente e demais membros do Conselho Universitário no qual constestavam 
veementemente a nomeação de J. Octaviano. De acordo com o Diário Carioca, o texto foi "assignado por quase todos os alumnos matriculados no Instituto de Musica". O jornal replicou parcialmente o documento e, no cerne das alegações, constava que "esse professor se acha[va] moralmente incompatibilizado com a classe, por factos tornados publicos na imprensa desta capital", complementando que isso obrigaria os signatários "a tomar atittude decidida e decisiva, caso os precarios direitos do sr. professor Octaviano consigam leval-o a reger o curso de contraponto e fuga" (DIÁRIO CARIOCA, 1934b, p. 3). Num só golpe, o movimento estudantil aumentava o nível da tensão e desmoralizava o professor, sustentando o repúdio a ele a partir da matéria que, meses antes, fora publicada anonimamente em um jornal carioca.

Ainda segundo o Diário Carioca (1934b, p. 3), o grave acontecimento dizia respeito a "uma queixa apresentada à polícia, no mês de dezembro do anno findo [1933], com relação a um caso em que se viu envolvido o maestro Octaviano e uma menor. Facto que foi até explorado escandalosamente por um matutino". J. Octaviano imediatamente retorquiu as acusações através de uma carta enviada ao jornal. Com o objetivo de "reestabelecer a verdade", o músico elencou quatro pontos em sua defesa:

[1] Não é exacto que o Conselho Universitário tenha me nomeado livre docente de contra-ponto e fuga. Ao contrario, eu sou o único livre docente daquella materia desde 1923 e, tendo a Congregação do Instituto reconduzido, no anno passado todos os meus collegas, o Conselho Universitario achou por equidade, que eu não podia ser excluido e devia portanto continuar.

$2^{\circ}$ ) - Tambem não é verdadeiro que o professor Leonel Gonzaga tenha se empenhado em minha defesa. O que se passou foi coisa muito diversa. Discutindo-se no Conselho Universitário, o memorial que enviei, o professor Fontainha fez os maiores elogios à minha capacidade technica, asseverando, ao mesmo tempo, que sobre a parte moral também nada se podia dizer contra mim, pois, até elle, director do Instituto de Musica, tinha ali na sua pasta, documentos que provavam o contrario. À vista disso, então, isto é, depois que o professor Fontainha fez de mim a mais completa defesa, foi que o professor Leonel Gonzaga e todos os outros conselheiros universitários estranharam o procedimento do Conselho Technico do Instituto de Musica. Apenas.

$3^{\circ}$ ) - Quanto a ter eu maculado a uma alumna minha, isso é uma calumnia que só pode haver nascido de uma informação anonyma. Nenhum dos meus inimigos é sufficientemente digno e decente para repetir isso com a assignatura de seu nome, afim de que eu possa responsabilizal-o criminalmente, processando-o na fórma da lei.

$4^{\circ}$ ) - Sobre o concurso, eu concordo inteiramente com a vossa opinião [abrir concurso público para provimento da vaga]. E o vosso Jornal prestaria um serviço inestimavel a mim e ao ensino, se conseguisse junto aos poderes públicos a abertura de concursos para provimentos das cadeiras vagas no Instituto de Musica' (DIÁRIO CARIOCA, 1934b, p. 3). 
E Guanabarino? Ao perceber que o desafeto fora levado às cordas e buscava se recuperar, partiu para tentar o nocaute. Quatro dias após a publicação na imprensa da carta-defesa de J. Octaviano, o crítico pauta longamente o tema em sua coluna, rebatendo diretamente alguns dos argumentos elencados pelo músico. O tom é um misto de desprezo e deboche:

\footnotetext{
[1] Ora, a parte cômica dessas declarações é ver o Sr. Fontainha [diretor do Instituto] elogiar a technica do $\mathrm{Sr}$. Octaviano relativa ao contraponto e fuga. $\mathrm{O}$ director do Instituto engazopou os membros do Conselho Universitario fazendo-se passar por conhecedor daquellas matérias, quando é certo que, apesar de ser director do Instituto Nacional de Musica, não conhece nem sequer a harmonia elementar. Não queremos discutir o resto, relativo aos Srs. Octaviano e Fontainha, para que não sejamos obrigados a gritar - Que ambos!

[2] Mais interessante, ainda, é quando o Sr. Octaviano Gonçalves exclama hypocritamente: '[transcreve literalmente a defesa de Octaviano em relação à acusação de macular uma de suas alunas].' Ó Sr. Octaviano!

Porque razão não processou, na fórma da lei, o vespertino que levantou essa lebre explorando o escândalo?!

A lei é clara. Não é preciso a assignatura do artigo injurioso para dar logar ao processo criminal. Ainda está em tempo. Chame o vespertino à responsabilidade, em logar de exclamações quixotescas, e esse vespertino saberá defender-se alegando que tudo quanto publicou foi por informações da Policia. Neste caso o Sr. Octaviano processará a Policia.

Vê-se, mais uma vez, o que vae lá pelo Instituto, e tudo isso porque aquelle estabelecimento está indevidamente ligado à Universidade do Rio de Janeiro tendo como director o Sr. Guilherme Fontainha (JORNAL DO COMMERCIO, 1934c, p. 2).
}

O caso é delicado e de difícil abordagem nos tempos de hoje, pois confronta duas pautas atualíssimas nos debates civilizatórios e socioculturais que ocorrem no Brasil:

1) Por um lado, a queima de uma reputação através da imprensa, na qual o acusado recebe uma sumária e antecipada condenação pública, sem direito a uma investigação isenta ou aos encaminhamentos de um devido processo legal. No caso específico de J. Octaviano, a denúncia ainda trazia a nuance de ser anônima;

2) Por outro, o episódio pode se conectar a uma tradição machista na qual o assédio ao corpo da mulher se configura em prática abominavelmente recorrente, muitas vezes levada a cabo no exercício de posições hierárquicas que podem suscitar condições vulneráveis à vítima (professor $\mathrm{x}$ aluna; patrão $\mathrm{x}$ empregada; homem mais velho $\mathrm{x}$ adolescentes ou crianças, etc.). Além disso, se ainda hoje é duro abordar o tema publicamente em função dos perigos e constrangimentos envolvidos, o quão difícil não o seria fazê-lo em 1933? Em tese, isto poderia explicar o anonimato na denúncia realizada contra J. Octaviano. 
Não foi possível reunir maiores detalhes em torno deste episódio e, neste caso específico, é impossível saber precisamente o que aconteceu sem a continuação de uma rigorosa investigação (o que escapa ao propósito do artigo). O que sabemos é que J. Octaviano acabou absolvido no Instituto Nacional de Música e não há notícias de que tenha tido qualquer implicação jurídica posterior. Era inocente e alguém plantou uma falsa denúncia na imprensa para destruir a sua carreira? É possível. Ou, culpado, foi acobertado por um sistema que ainda hoje transforma recorrentemente vítimas em vilãs? Outra hipótese plausível. Pesquisas futuras poderão nos responder mais precisamente tais indagações. Aqui, o que fundamentalmente nos importa é tanto manter um olhar crítico sobre ambas as práticas (a destruição injusta de reputações e o machismo estrutural), reprováveis em todos os sentidos, quanto indicar a que níveis chegavam (e chegam) as lutas travadas dentro do campo da música de concerto. As disputas por espaços extrapolavam o âmbito institucional e poderiam se converter, literalmente, em casos de polícia.

A partir do segundo semestre de 1934, depois de atravessar os meses mais difíceis da conflagração, J. Octaviano voltou a ocupar as páginas da imprensa carioca por suas atividades musicais, inclusive assinando um grande contrato com o Theatro-Escola para compor o seu quadro técnico e responder pela produção musical dos espetáculos da companhia.

THEATRO ESCOLA - A direção do Theatro Escola acaba de fechar um contrato que reputa de grande alcance para as finalidades artísticas do seu programma: o da senhorita Eros Volupia, bailarina brasileira que tantos applausos tem conquistado da critica e do publico.

E sendo a dansa uma expressão musical, ella exige o maestro compositor que lhe dê o rythmo da forma; attendendo a essa necessidade, o Theatro Escola fechou outro contrato igualmente valioso: o do maestro J. Octaviano, nome que dispensa justificações.

O maestro J. Octaviano actuará como um dos orgãos Technicos do Theatro Escola, que aproveitará, na medida das suas possibilidades, os valores brasileiros que desejem prestigial-o com o seu concurso (CORREIO DA MANHÃ, 1934a, p. 8).

A partir de então, o nome do músico é recorrentemente destacado nos jornais em uma longa sequência de espetáculos cuja música orquestral é composta (ou adaptada), 
regida, ensaiada e/ou produzida por ele, algumas vezes estabelecendo diálogos estreitos com a coreografia da bailarina Eros Volupia ${ }^{19}$.

Figuras 7, 8 e 9 - "Do maestro J. Octaviano basta assignalar que elle é premio de viagem de composição e instrumentação conferido pelo Instituto Nacional de Música [em 1922]”.

\section{NOTAS \& NOTICIAS}
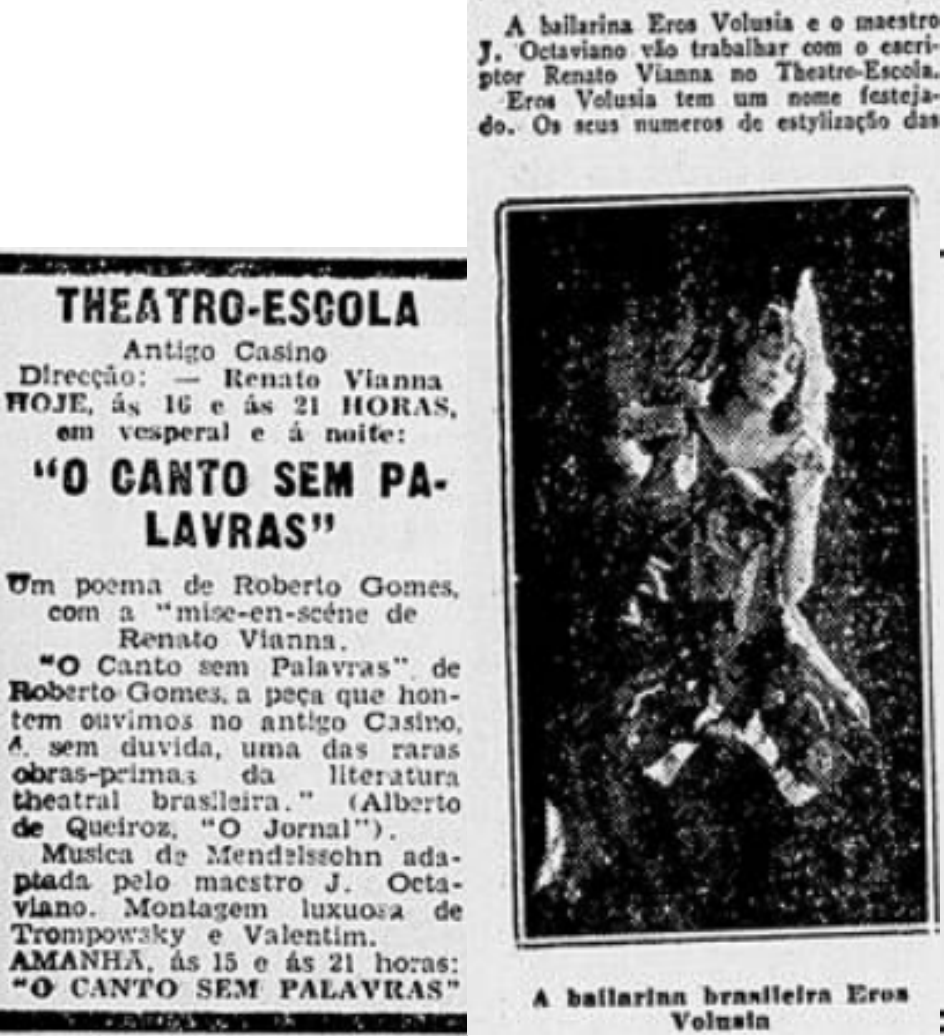

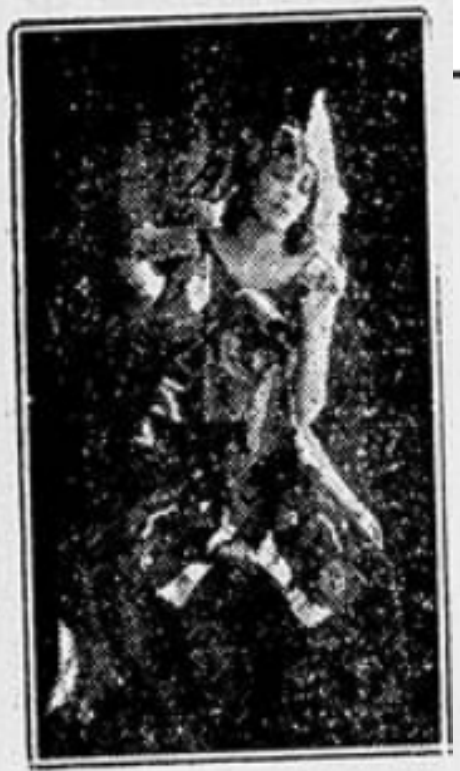

A ballarinn branllelra Eres Volnala

\section{THEATRO-ESGOLA} Ex-Casino Direcçå: - Renato Vianna "O DIVINO PERFUME"

a peca que Renato Vianna es. creve para a propagenda sevolucionaria no Nordeste brasiletro e que todo o paiz fa spplaudiu e consagrou

HOJK, em VESTERAL, e á noite: ás 15 e 21 horas.

Esgotadas as lotacóes de hontem Brihante actuaço de Jayme Costa (erendot da peça), Delorses Caminha, Olga Navarto. Itsilia Fausta e Lucia Deto:

Parto musical sob a direçấo

do maestro J. Octaviano. Na proxims semana:

"Historia de Carlitos" de Henrique Pongetti.

Fonte: O Radical 1934, p.4. Fonte: Correio da Manhã 1934b, p. 12. Fonte: O Radical 1935a p. 5.

Parte destas peças foram grandes produções protagonizadas nos principais palcos do Rio de Janeiro, incluindo o Theatro Municipal. Uma delas, Deus, chegou inclusive a abrir, em 1935, a programação oficial da temporada de inverno da casa.

19 Na crítica da peça Sexo, por exemplo, Mario Nunes, articulista do Jornal do Brasil, pontua: "Eros Volusia, cuja mascara é expressiva, deu à musica do maestro J. Octaviano movimento e mais acentuada emoção, traduzindo bem a ideia do autor" (JORNAL DO BRASIL, 1934, p. 15). 
Figura 10 - Anúncio do espetáculo Deus, do Theatro-Escola, com “imponente colaboração musical do Maestro J. Octaviano, que regerá a orquestra e um coro de Professores".

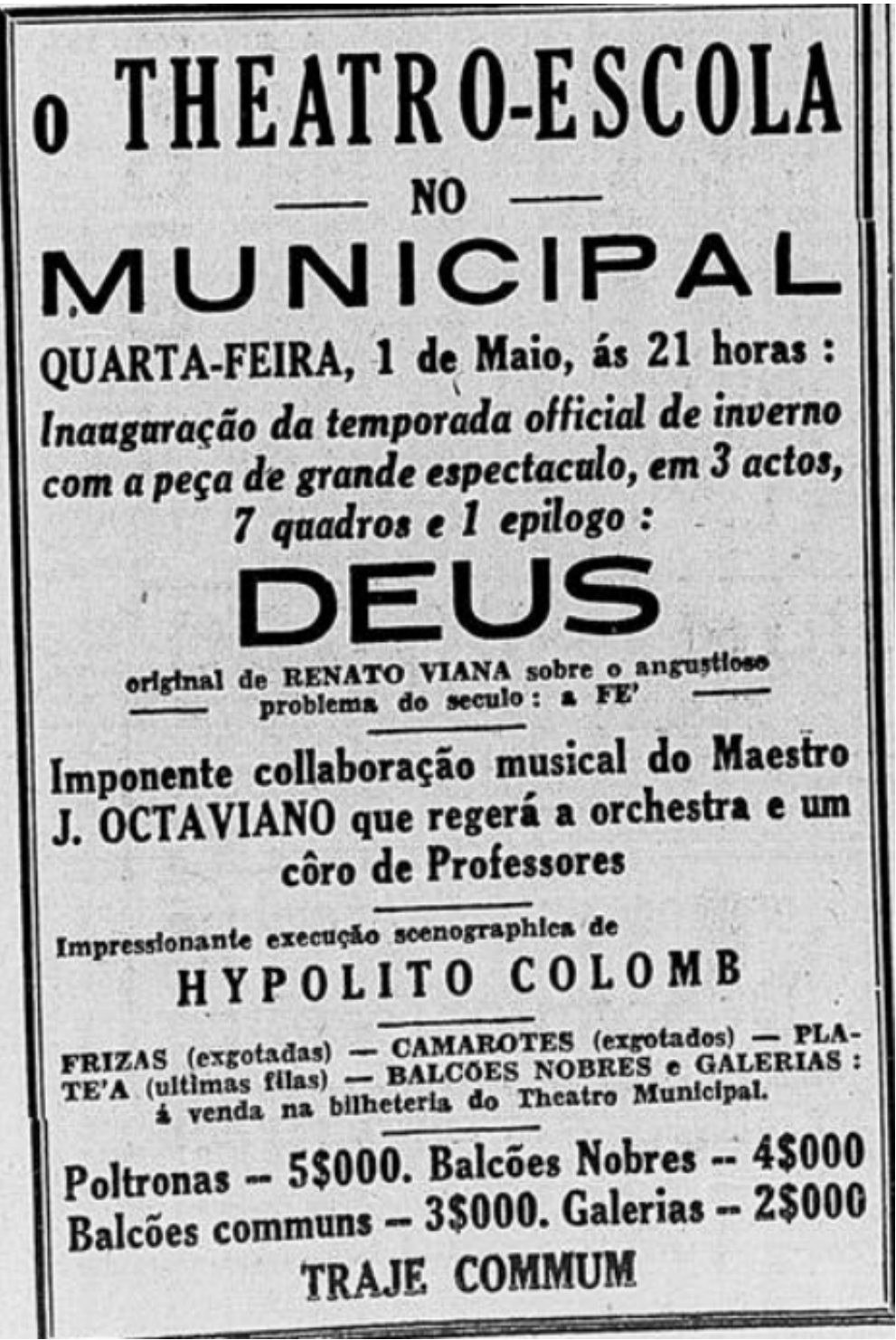

Fonte: Diário Carioca 1935a, p. 15.

Os espetáculos seguiram ganhando ampla repercussão na imprensa e o nome de J. Octaviano volta à baila com força, tornando-se paulatinamente uma referência como compositor e regente de trilhas sonoras para teatro, dança e cinema. "A musica que envolve 'Deus' é uma partitura emocionante, obra inspirada e apropriada, do maestro J. Octaviano $^{20 "}$ (DIÁRIO DA NOITE, 1935, p. 5).

\footnotetext{
${ }^{20}$ Um coro quase uníssimo nos jornais cariocas: “[...] 'Deus' tem momentos musicaes de grande emoção. A colaboração musical é do maestro J. Octaviano que fez paginas commovedoras e inspiradas" (O RADICAL, 1935b: 4); "[...] Essa pagina de rythmos harmoniosos e balsâmicos foi composta pelo maestro J. Octaviano (DIÁRIO CARIOCA, 1935b, p. 14).
} 
O músico participou de dezenas de produções em diálogo com outras artes e, em cada uma delas, ganhava uma nova rodada de confetes nos jornais da capital. Um dos gêneros mais celebrados foram os seus bailados, cujo valor musical foi particularmente destacado por parte da crítica:

\section{CORREIO MUSICAL. ESPECTACULO DE BAILADOS NO MUNICIPAL}

[...] Obtiveram incontestavelmente as honras da noite, pela originalidade e imaginação mais alerta, tres numeros musicais e choreographicos do maestro J. Octaviano, que os regeu pessoalmente: 'A Boneca do Lixo', a 'Dansa Geometrica' e o 'Principe de duas mascaras'. ${ }^{21}$

Foram tres bailados dignos de menção pela belleza da composição musical, sempre de bello effeito e excellente estructura, e pela novidade da choreographia. [...] Torna-se necessario aqui salientar a 'Dansa Geometrica', não apenas pelos gestos seccos e mecanicos, pelo cubismo da imaginação, mas sobretudo pela feliz tentativa musical do seu autor em realizar uma obra nova, inedita, por assim dizer, exclusivamente mecanica, com instrumentos de percussão, fazendo com que a variedade dos rythmos correspondesse à evolução dansante.

Foi um numero que valeria por todo o espectaculo. Para o 'Principe de duas mascaras' Octaviano compoz ainda uma musica barbara e verdadeiramente adequada ao assumpto. [...]. JIC. [João Itiberê da Cunha] (CORREIO DA MANHÃ, 1936, p. 7).

Guanabarino foi, novamente, o contrapeso da balança. Primeiro, recebeu com desconfiança a notícia da contratação de J. Octaviano pelo Theatro-Escola, mais uma vez botando pejorativamente J. Octaviano e Villa-Lobos no mesmo saco.

[...] o nosso proposito era tratar dos últimos acontecimentos musicaes ocorridos durante a semana. Quasi não houve movimento digno de menção; em todo o caso lemos a grata noticia dada pelo director do Theatro-Escola de haver contractado uma bailarina e um compositor de bailados... Não se assustem. Esse compositor não é o barulhento maestro Villa-Lobos. Não! É o celebre interprete da Sonata ao Luar, qualificativo que faz logo adivinhar que se trata do professor Octaviano Gonçalves. A bailarina tem nome de homem - Eros - deus do Amor, e vae por em embaraços o compositor, porque não se trata de uma dançarina vulgar, e sim de uma discipula dos pássaros, dos ventos, das nuvens e das arvores, e que por isso mesmo remexe a peneira das suas criações como a remexem os pássaros, os ventos, as nuvens e as arvores.

O diabo é que o director desse Theatro-Escola, sendo dramacturgo e comediante, embarafusta-se pela dança e pelas symphonias dançantes como quem descrê do apoio publico para os dramas e comedias sem danças e sem musica. [...] Oscar Guanabarino (JORNAL DO COMMERCIO, 1934d, p. 2).

Note-se que Guanabarino ataca justamente alguns dos pontos mais destacados pelos articulistas de outros jornais: os bailados, a parceria com a bailarina Eros Volupia e o

${ }^{21}$ Das cerca de 400 obras de J. Octaviano que conseguimos levantar, constam estes três bailados, localizados dentre os manuscritos não catalogados do arquivo passivo da Biblioteca Alberto Nepomuceno (BAN), que integra a Escola de Música da Universidade Federal do Rio de Janeiro (UFRJ). 
cruzamento da música com outras modalidades artísticas (ou vice-versa). Entretanto, o que mais parecia incomodá-lo era o reconhecimento público angariado por J. Octaviano neste terreno, bem como a possível soberba que o músico havia incorporado a partir de seu sucesso. Em novembro de 1934, por exemplo, assina uma crônica em que relata a suposta conversa que teve com um dos professores do Instituto e outros amigos em sua residência, dizendo que os presentes haviam se estranhado em função das posições divergentes em relação ao diretor da instituição, Guilherme Fontainha. Segundo o crítico, a situação só foi remediada porque todos riram de uma anedota que tinha Octaviano como protagonista.

E foi por ahi, o diabo do homem [o professor do Instituto que visitava a sua casa], cujo nome não declinamos para que a sua modestia não se offenda. Depois do seu discurso [em defesa do diretor Fontainha], que durou quasi meia hora, amarrou a cara e só esboçou um sorriso quando um dos companheiros da roda, falando dos bailados que o maestro Octaviano Gonçalves vae escrever para o Theatro-Escola provocou um seu aparte, e perguntou malevolamente:

- Vocês já viram como elle anda agora? O ventre estufado, todo elle empertigado, olhando para os miseros mortaes com a sobanceria dos homens celebres na arte dos murros e dos ponta-pés? Caminha esperando sempre que o povo o acclame. Tenho pena delle. Vae sofrer uma operação cirúrgica...

- Apendicite?

Não! A radiografia descobriu que elle tem um rei na barriga! É preciso operal-o.

E levantaram-se todos, a rir, começando as despedidas até que se deu o toque de retirada [...]. Oscar Guanabarino (JORNAL DO COMMERCIO, 1934e, p. 2).

A essa altura, com mais de 90 anos, o longevo crítico caminhava para os anos finais de sua vida mantendo afiadíssima a ponta da pena. A idade começava a pesar, porém, foi a suposta morte de J. Octaviano quem primeiro lhe pregou uma peça. Em 16 de novembro de 1935, Guanabarino inscreve as seguintes palavras na lápide do músico.

Depois de tão alegres noticias sobre uma pianista patrícia [Yolanda Ferreira $^{22}$ ], temos que colocar a nossa penna em funeral emquanto rezemos uma prece em favor da alma de um outro pianista que não era grande coisa, mas que tantas vezes serviu de assumpto a estas columnas.

Foi na secção musical do Correio da Manhã que encontramos a infausta noticia dizendo assim: - 'O programma é o seguinte, de reverencia à memória de três grandes compositores brasileiros'.

Esses grandes compositores mortos e agora reverenciados pelo Correio da Manhã são - Henrique Oswald, Octaviano Gonçalves e Alberto Nepomuceno.

\footnotetext{
${ }^{22}$ Ao referenciar a pianista, o crítico reafirma como a questão da filiação lhe era cara: "Sabe-se que a professora Yolanda Ferreira é uma pianista de grande valor não só pela technica extraordinária, mas ainda pela sua escola e pela sua arte" (JORNAL DO COMMERCIO, 1935', p. 2).
} 
Não sabíamos já estar na eternidade o bello e guapo Octaviano Gonçalves. E o probresinho morreu, não se sabe quando, sem a bandeira nacional a meio pau no maestro do Instituto do Largo da Lapa; e sem missa, sem enterro de $1^{\text {a }}$ classe custeado por suas alumnas, sem panegyrico nos jornaes, sem retrato nas revistas, sem nada, enfim, como se fosse apenas o simples chauffeur amador registrado sob o numero 13.444 nos archivos da Inspectoria dos Vehiculos...

Bem disse Horacio: - aeque pulant [pulsat] pede $e^{23}$

Em todo o caso - Requiescat in pace [descanse em paz]! Amen!

Oscar Guanabarino (JORNAL DO COMMERCIO, 1935a , p. 2).

O epitáfio que Guanabarino dedica a Octaviano, por coerência, não poderia deixar de ser debochado e depreciativo, uma vez que estas foram as duas marcas recorrentes no trato dedicado àquele que chamava de chauffeur. Cumpre notar que o articulista parece regozijado com o fato de o desafeto ter "morrido" sem homenagens ou alardes, sem discursos ou retratos nos jornais, sem a pompa e circunstância das matérias laudatórias que tanto o incomodavam. O motorista, enfim, no seu devido ostracismo. Ainda que para isso Guanabarino tivesse que engolir a seção musical do Correio da Manhã assinada pelo respeitado João Itiberê da Cunha, o $J I C$, fazendo uma "reverência à memória de três grandes compositores brasileiros", ladeando J. Octaviano a vultos como Alberto Nepomuceno e Henrique Oswald.

Nas entrelinhas, porém, é possível perceber que o crítico considerava uma outra estatura para J. Octaviano. É quase contraditório quando afirma que o pianista "não era grande coisa", mas logo em seguida reconhece que ele "tantas vezes serviu de assunto" às suas colunas. Ora, um personagem perspicaz como Guanabarino bateria em um cão vira-lata durante três décadas? Era inteligente demais para escolher adversários históricos que estivessem muito distantes do seu próprio tamanho (ou do que julgava ter). As lutas renhidas que travou com J. Octaviano eram, antes, embates de representatividade, disputas por espaços oficiais e pelo controle da hegemonia de setores práticos e simbólicos no campo da música de concerto.

Em conflitos dessa natureza, só há um enfrentamento prolongado (e equilibrado) se há algum nível de equivalência entre as forças contrárias. Ou melhor, se os movimentos

\footnotetext{
${ }^{23}$ Guanabarino se refere a um excerto poético do antigo filósofo e escritor romano Horácio ( 65 a.C -8 a.C), contido em uma de suas célebres Odes (1, 4-13): Pallida Mors aequo pulsat pede pauperum tabernas / regumque turres. Em tradução livre: "A pálida Morte bate, com o mesmo pé, nos casebres dos pobres / e nas torres dos reis". Fonte:

https://estadodaarte.estadao.com.br/parirao-os-montes-nascera-um-ridiculo-rato-ou-um-pouco-sobre-aarte-poetica-de-horacio/

Acesso em 03 set. 2020.
} 
de um e outro lado são capazes de influenciar minimamente o rumo e o roteiro dos jogos no tabuleiro do poder instituído. Não parece por acaso que tantas vezes o crítico tenha embrulhado Villa-Lobos e J. Octaviano em um mesmo pacote. Guanabarino sempre tratou de todas as espécies de mesquinharias que envolviam as instituições, os personagens e as práticas musicais de seu tempo, mas certamente seus adversários históricos - os principais - eram escolhidos a dedo. A remissão aos versos de Horário não é fortuita: era um rei que acabava de tombar com a suposta morte de J. Octaviano, ainda que através da mesma foice que vitima os pobres em casebres.

Para seu desespero, entretanto, o alarme era falso e Guanabarino foi obrigado a se retratar na coluna seguinte, culpando a coluna musical do crítico e "erudito colega" João Itiberê da Cunha, o JIC, pela barrigada: "Ajustemos as nossas contas com o 'Correio da Manhã', folha que nos pregou o logro matando o professor Octaviano Gonçalves, que o vimos hontem cheio de vida e belleza, gingando a sua formosura e espalhando o terror das conquistas" (JORNAL DO COMMERCIO, 1935b, p. 2). Como se nota, ao ser obrigado a "reviver" o desafeto, Guanabarino não se furta a fazê-lo resgatando a sua péssima fama de D. Juan.

Em 17 de janeiro de 1937, pouco mais de um ano após este episódio, a morte lhe pregaria outra peça, desta vez verdadeira e definitiva, ao lhe ceifar a vida em decorrência das complicações de um câncer na faringe. Segundo Passamae, o fato "repercutiu muito na imprensa" e o cortejo funerário foi acompanhado por nomes destacáveis das artes, da política e dos jornais, além de "numerosos amigos e colegas" (2017, p. 38). Tombava, enfim, o símbolo de uma era na crítica musical brasileira.

Não chegou a ver e ouvir, naquele mesmo ano, alguns de seus desafetos ganharem as ondas de rádio e as páginas do jornal em que assinou a famosa coluna Pelo Mundo das Artes durante duas décadas (1917-1936), tomados então como "grandes mestres" e nomes emblemáticos da história da música no Brasil. 
Figura 11 - Programa da Rádio Tupi, em 30 de dezembro de 1937, com obras de Octaviano Gonçalves, Villa-Lobos, Leopoldo Miguez e Barroso Netto.

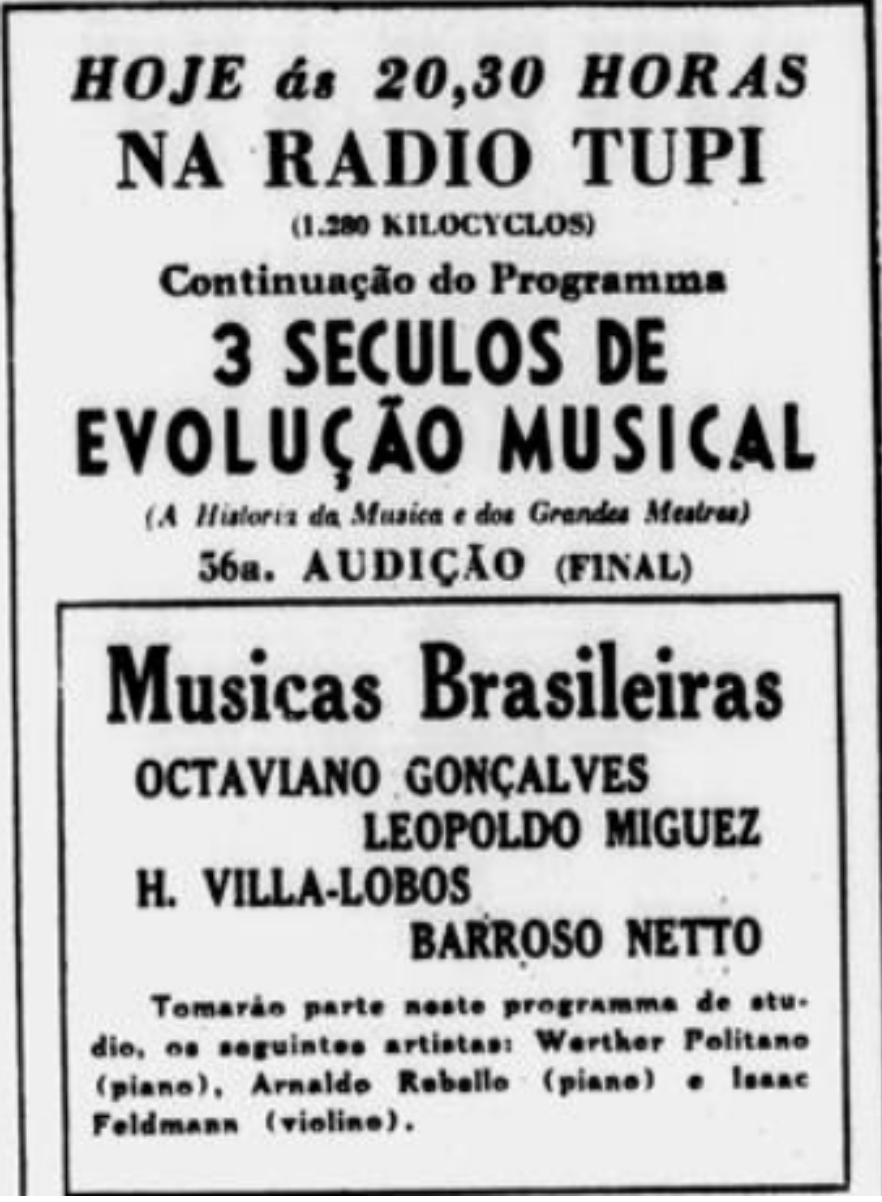

Fonte: Jornal do Commercio 1937, p. 13.

Fosse vivo, certamente guardaria alguns de seus parágrafos para reclamar desta reunião de "sambeiros" e chauffeurs. Mas as lutas de representatividade que tanto travara em vida sobreviveriam a ele, permanecendo ativas em outro campo: o da memória.

\section{Considerações finais}

"Aquilo a que se chama explicação é apenas a maneira do relato se organizar em intriga compreensível" (VEYNE, 1978, p. 67). Em História Cultural: entre práticas e representações, o historiador francês Roger Chartier evoca esta sentença de Paulo Veyne (1930) para demonstrar como os ordenamentos, composições e atravessamentos dos relatos (históricos ou ficcionais) são, por dois caminhos, decisivos para forjar as narrativas de compreensão histórica: um primeiro, na linha de Veyne, “considerando ao mesmo tempo que contar é sempre dar a compreender e, consequentemente, explicar em 
história não é mais do que desvendar uma intriga" (CHARTIER, 2002, p. 82); e um segundo, desdobramento do primeiro, sugerindo que os fenômenos históricos só podem ser inteligíveis "a partir dos cruzamentos dos seus vestígios acessíveis", o que abrigaria a perspectiva de reconstruir as faces menos visíveis das realidades que os produziram (ferramentas de controle, leis silenciosas, lutas de representatividade, interesses de grupo, etc.).

[...] a proposta que liga narração e explicação pode ter um outro sentido, se elaborar os dados colocados na intriga como vestígios ou indícios que permitem a reconstrução sempre submetida a controle, das realidades que os produziram. $\mathrm{O}$ conhecimento histórico é assim inscrito num paradigma do saber que não é o das leis matemáticas nem tão pouco o dos relatos verosímeis. A encenação em forma de intriga deve ser entendida como uma operação de conhecimento que não é da ordem da retórica mas que considera fulcral a possível inteligibilidade do fenômeno histórico, na sua realidade esbatida [ou seja, impossível de se reconstruir totalmente], a partir do cruzamento dos seus vestígios acessíveis (CHARTIER, 2002, p. $82-83)$.

Neste estudo, intentamos promover o cruzamento de alguns destes vestígios relativos às disputas práticas e simbólicas que giraram em torno da música de concerto no Brasil durantes as primeiras décadas do século XX, tomando como casos particulares o papel polarizador do Instituto Nacional de Música e a posição/relação de dois personagens que figuravam dentre os mais ativos no campo musical brasileiro daquele momento: o compositor, pianista e professor João Octaviano Gonçalves (1892-1962) e o crítico Oscar Guanabarino (1841-1937). Um dos pontos decisivos foi tentar desvelar algumas das camadas soterradas que compuseram o campo de concorrências no qual ambos atuavam, conectando as projeções individuais aos interesses de grupo. Em outras palavras, reconhecer que ao lado das trajetórias e crenças pessoais se articulam forças coletivas de representação que são decisivas para ensejar posicionamentos. Por isso, a importância de se relacionar "os discursos proferidos com a posição de quem os utiliza" (CHARTIER, 2002:17) ou, ainda que parcialmente, resgatar "o gesto que liga as 'ideias' aos lugares" (CERTEAU, 1982, p. 64).

As batalhas de representatividade não são forjadas através de posições neutras. Nelas, há sempre a perspectiva de se impor a autoridade de um discurso à custa de outros, ora menosprezados para que um determinado projeto seja justificado e legitimado duplamente: aos próprios indivíduos que o professam e ao campo mais amplo no qual se inserem. (CHARTIER, 2002, p. 17). Neste sentido, o próprio Chartier nos recorda que, 
em torno das práticas culturais e dos bens simbólicos, o que está em jogo é a disputa pelo poder de classificar, hierarquizar, consagrar e/ou (des)legitimar. (CHARTIER, 1994, p. 184).

Portanto, a análise de juízos estéticos inseridos neste campo de batalhas não deve desconsiderar as relações (quase intrínsecas) com as manifestações deste poder (GOLDBERG; OLIVEIRA, 2019a, p. 24). Bourdieu nos alerta que os historiadores de arte e os teóricos da estética "estão comprometidos, sem o saber, ou sem tirar disso, em todo o caso, todas as consequências, nas lutas em que se produzem o sentido e o valor da obra de arte" (1996, p. 330). Este conceito também diz respeito ao trabalho de musicólogos, críticos, artistas e instituições culturais. Deliberadamente ou não, todos estamos engajados na produção de sentidos em relação aos nossos objetos de estudo.

Diante destas questões, é possível sugerir que três aspectos mais decisivos atravessaram a relação de J. Octaviano e Oscar Guanabarino:

1) O papel polarizador do Instituto Nacional de Música. Reverberando os debates institucionais e estéticos que ocorriam em torno da música de concerto oficial, os embates históricos de Guanabarino com esta instituição foram sintetizados pelo próprio crítico, no fim de sua vida, através de uma curiosa anedota. Ao justificar um boato indevido sobre o seu estado de saúde, escreveu:

Parece incrível, mas contra factos não há argumentos.

Os leitores destes folhetins talvez não acreditem no que lhes vamos narrar; mas temos, á disposição de quem duvidar e de quem fôr curioso, varias cartas, cartões e até telegrammas indagando da nossa preciosa saude, sem contar as telefonadas que começaram quarta-feira e só cessaram dois dias depois; tudo isso em indagações assustadas, de amigos, e sorridentes de inimigos.

E tudo partiu de uma simples frase pronunciada por um professor do Instituto quando, no armazém da Casa Arthur Napoleão, pachorrentamente terminou a leitura do Pelo Mundo das Artes da semana passada. Disse elle, então, aos amigos que o rodeavam: - 'O Guanabarino está doente! E talvez gravemente doente!'

Entreolharam-se os amigos; e afinal interrogaram-no. 'É que elle neste folhetim, não falou mal de ninguém; e até poupou o Instituto. Vou visitalo' (JORNAL DO COMMERCIO, 1934e, p. 2).

Muito jovem, J. Octaviano ganhou prêmios e foi alçado ao posto de livre-docente do Instituto Nacional de Música após concluir com medalha de ouro o seu curso de piano. Quando ainda estudante, recebera críticas positivas de Guanabarino, que elogiava seu talento e interpretações “perfeitas”, um aluno que honrava a cátedra de seu célebre mestre, Henrique Oswald (1852-1931). Todavia, depois de se vincular como professor do 
Instituto e passar a representar uma escola pianística e estilística que se distanciava daquela professada pelo crítico, o músico foi por três décadas achincalhado técnica, musical e pessoalmente por Guanabarino em dezenas de suas colunas. Como ilustração, vale destacar os epítetos que recebeu: Zé Octaviano, Juca Gonçalves, Jotinha Octaviano, Grande Jotinha, bibliotecário, arquivista, bicho muito feio, urubu malandro, pavão e, sobretudo, chauffeur, o ilustre motorista da música brasileira.

Por décadas seguidas, Guanabarino foi uma importante voz a escrutinar todas as espécies de despautérios que envolveram a instituição (e não foram poucas). Não é por acaso que uma das primeiras aparições de J. Octaviano na coluna Pelo Mundo das Artes tenha sido para denunciar a sua atuação na banca de um concurso para professor de piano da casa. Entretanto, é necessário compreender o seu engajamento dentro de um contexto mais amplo: ora dando a entender que não era convocado a participar de bancas como modo de se evitar um juiz severo, ora destacando que não fora chamado a escrever na revista musical do estabelecimento porque os professores responsáveis não passavam de prevaricadores, em muitas passagens o crítico deixa notar que as suas revoltas eram imediatamente proporcionais ao não reconhecimento que o Instituto oferecia tanto à sua persona quanto ao seu ideário artístico, um tratamento que ele retorquia à altura, classificando o estabelecimento como "leproso", pródigo em protagonizar balbúrdias e estragar alunas promissoras: "Escândalos não faltam no Instituto: e agora, depois que batalhamos a um rol de annos, é que a imprensa carioca está tomando interesse pelo que se passa ali, criticando alguns casos que ecoaram cá fora" (JORNAL DO COMMERCIO, 1934c, p. 2).

Já em 1917, após voltar a comentar alguma atividade musical da instituição, o crítico confessara: "estivemos durante muito tempo affastados do Instituto Nacional de Música" (O PAIZ, 1917, p. 3). Diante dos raros gestos de aproximação de ambas as partes, este distanciamento só se agravou ao longo das duas décadas seguintes, com cada polo buscando se estabelecer como o eixo mais forte de representação da música de concerto oficial do Rio de Janeiro. O olhar crítico de Guanabarino para J. Octaviano, portanto, não pode ser aludido sem levar em consideração que o professor era, naquele momento, uma das faces públicas mais emblemáticas do Instituto Nacional de Música. 
2) A disputa pela hegemonia da melhor escola de piano. À primeira questão, somam-se as questões particulares em torno deste instrumento, praticado e ensinado tanto por Guanabarino quanto por J. Octaviano. Antes de tudo, tratava-se de reivindicar uma assinatura: quem poderia responder pela escola mais forte de formação pianística do Rio de Janeiro? Neste sentido, observamos como as alunas e alunos foram recorrentemente utilizados, através da imprensa, como meios para ratificar ou questionar as capacidades professorais de ambos.

A questão era tão premente que Guanabarino se referia às partidárias usando termos próprios de núcleos familiares: eram as suas "netinhas", filhas de suas filhas (alunas). Neste processo, foram flagrantes as disputas em torno das cadeiras para professor de piano do Instituto Nacional de Música e as tentativas do crítico de esvaziar o poder da assinatura de J. Octaviano como professor, desqualificando a sua competência para ensinar as alunas mais avançadas (que, segundo ele, andavam para trás diante de suas lições) e o acusando de se apropriar indevidamente dos trabalhos que herdara de outros mestres, como Henrique Oswald e Haydée Mor Meyl.

3) Divergências estéticas e estilísticas. Guanabarino foi, em termos gerais, um personagem cujo pensamento artístico estava mais fortemente ligado à tradição. Para ele, os elementos principais da música eram melodia, harmonia e ritmo, preferindo a simplicidade de uma bela melodia às "barulhadas insuportáveis" da música de VillaLobos, por exemplo (JORNAL DO COMMERCIO, 1932b, p. 2). Naturalmente, atuando ininterruptamente por mais de meio século e sendo testemunha ocular de transformações socioculturais profundas e mudanças de paradigmas estéticos, algumas de suas posições se reconfiguraram, como na leitura da produção do alemão Richard Wagner (1813$1883)^{24}$. Ainda assim, cumpre notar que se tratava de uma "admiração pelo belo científíco e não pelo belo musical” (GOLDBERG; OLIVEIRA, 2019, p. 22). Não era, portanto, um personagem completamente engessado, mas que manteve coerente até o fim da vida o elo mais forte com a música ancorada nas competências e autores tradicionais, que ele julgava injustamente obliterados por uma arte que não tinha o mesmo valor: "Valha a verdade,

\footnotetext{
24 “Quanto a Wagner e sua música, a mudança de atitude ocorrida foi extraordinária e surpreendente. Se em 1896 Vianna da Motta o tinha como o valente adversário do wagneriano Luiz de Castro, crítico da Gazeta de Notícias, e vigoroso defensor da música italiana (SOLFEJANDO, 1896, p. 2), é admirável como O Malho, em 1934, o descreve como um ardoroso wagneriano" (GOLDBERG; OLIVEIRA, 2019a, p. 22).
} 
no entanto, que nos obriga a reconhecer a victoria do regional e de tudo quanto é deles, sobre os vencidos de hoje, ídolos de outrora, condemnados ao esquecimento e até ao desprezo - Bach, Haydn, Mozart, Beethoven, Chopin, Wagner, Liszt e tantos outros" (JORNAL DO COMMERCIO, 1930, p. 2).

Ao longo do artigo, pudemos constatar que o crítico foi veementemente contra a entrada de J. Octaviano, Radamés Gnattali ou Villa-Lobos como professores do Instituto Nacional de Música, assim como desprezava mestres e diretores que guardavam alguma relação com as manifestações culturais que escapavam à tradição mais estrita da música de concerto (casos de Lorenzo Fernández e Fertin de Vasconcellos). Para Guanabarino, o que colocava personagens tão diversos em um mesmo pacote era justamente o aproveitamento de caracteres das tradições populares, folclóricas e/ou indígenas em suas produções, algo pelo qual guardava verdadeira ojeriza. Mesmo nas raras vezes em que reconhece o valor de obras que dialogavam com estes gêneros, o faz sob a insigne de quem desejava inseri-las na tradição europeia. Em 1890, quando elogia o Samba de Alexandre Levy (1864-1892), por exemplo, é porque "a propriedade do trabalho era tal que poderia ser 'assignado por qualquer mestre de renome europeu" (GOLDBERG; OLIVEIRA, 2019a, p. 18). Villa-Lobos, o "sambeiro", que o diga.

Embora J. Octaviano não fosse estritamente modernista ou nacionalista, a partir de meados da década de 1920, parte considerável de sua produção passou a dialogar com o ideário de Mário de Andrade (1893-1945), personagem com quem trocou cartas e que lhe dedicou críticas elogiosas. O pensador brasileiro o tinha em tamanha consideração como compositor e pianista que adotava as suas peças nas aulas de piano que ministrava em São Paulo ${ }^{25}$. Esta aproximação de J. Octaviano com a "música característica" foi particularmente significativa durante os anos de 1920 e 1930 (precisamente quando recebe as críticas mais duras de Guanabarino), manifestando-se tanto no seu trabalho como compositor e regente quanto no de intérprete e professor. Vejamos o programa de um concerto protagonizado por ele em 1928:

\footnotetext{
${ }^{25}$ Por motivos espaciais e por exigir um referencial teórico próprio, a relação entre ambos está sendo aprofundada em um estudo específico.
} 
Figura 12 - Programa de "música característica" de J. Octaviano em dezembro de 1928. Músicas de Sá Pereira, Sebastião Barroso, Alberto Nepomuceno e do próprio Octaviano.

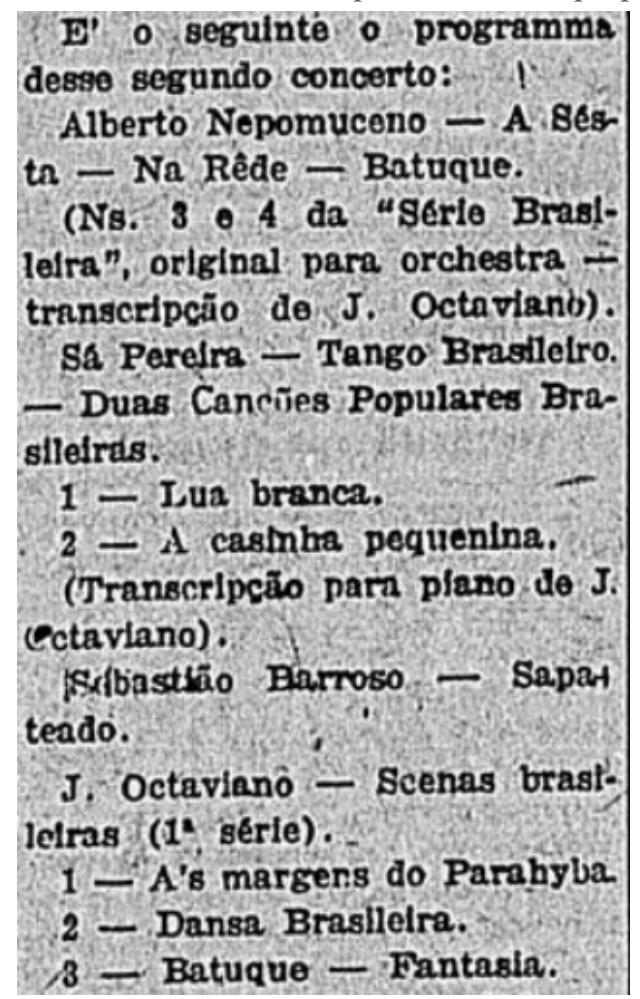

Fonte: CORREIO DA MANHÃ, 1928, p. 5

Guanabarino quase sempre torceu o nariz para esses cruzamentos. Em tom irônico, chega a comentar a presença reiterada de uma destas peças nos programas de concerto de J. Octaviano, o Tango Brasileiro, de Antônio de Sá Pereira (1888-1966), outro professor do Instituto Nacional de Música com quem teve altercações públicas.

[...] os dirigentes dessas festas [concursos de músicas regionais ou carnavalescas] deviam tentar, nas camadas do povo, a introducção das altas producções dos nossos grandes compositores que já se dedicaram ao regionalismo explorando os rythmos africanos e os requebros maxixeiros daquilo que é nosso.

Não conhecemos bem a literatura desse genero, mas sabemos, por exemplo, que o Sr. Sá Pereira compôs um Tango que facilmente se vulgarizou em São Paulo e que aqui, nos celebres recitaes do afamado pianista Octaviano Gonçalves, tem feito as delicias do auditorio dessas festas musicaes. Não julguem que percamos o nosso precioso tempo lendo esse genero de composição popular: mas foi elle proprio, o Sr. Sá Pereira, quem, com o seu folheto macaco, divulgou aquella preciosidade digna da maior divulgação (JORNAL DO COMMERCIO, 1934f, p. 2).

Fica nítido que o crítico não via com bons olhos esta vinculação (ainda que parcial) de J. Octaviano a um campo estético que buscava sistemicamente as interfaces da música de concerto com as tradições artísticas populares, folclóricas e/ou indígenas, um movimento que teve forte ascendência nos compositores brasileiros durante a primeira 
metade do século XX, reverberando os ares da Semana de Arte Moderna de 1922 e o ideário nacionalista de Mário de Andrade. De forma direta e depois de reconhecer que não dominava a literatura do gênero, Guanabarino resumiu o que pensava sobre o assunto: "não julguem que percamos o nosso precioso tempo lendo esse gênero de composição popular".

Para além dos méritos ou crenças pessoais, o que esteve (e está) em disputa é a hegemonia sobre algumas das práticas de um campo artístico marcado por interesses de grupo, leis silenciosas, ferramentas de controle e lutas de representatividade. De forma consciente ou inconsciente, estes embates subliminares são guias decisivos para a escolha de posicionamentos políticos, institucionais, estéticos, estilísticos, éticos, morais e pessoais, em demarcações e defesas de território que são formuladas, segundo Bourdieu (1996, p. 332), “em nome de uma pretensão à universalidade, ao julgamento absoluto, que é a própria negação da relatividade dos pontos de vista". O sociólogo nos alerta que as guerras de narrativas em torno do "pensamento essencial" são particularmente notáveis nos campos religioso, científico, jurídico, literário, artístico e de produção cultural, o que é estrondosamente manifesto na realidade brasileira atual. Quase um século antes, Oscar Guanabarino e J. Octaviano não escaparam à regra: "Se existe uma verdade, é que a verdade é uma aposta de lutas” (BOURDIEU, 1996, p. 332).

\section{Referências}

ANDRADE, Mário de. Música, doce música. São Paulo: L. G. Miranda editor, 1933.

AZEVEDO, Luiz Heitor Corrêa de. 150 Anos de Música no Brasil (1800-1950). Rio de Janeiro: José Olympio, 1956.

AZEVEDO, Luiz Heitor Corrêa de. 150 anos de música no Brasil (1800-1950). $2^{\mathrm{a}}$ ed. Rio de Janeiro: Fundação Biblioteca Nacional, 2016.

BOURDIEU, Pierre. As regras da arte: gênese e estrutura do campo literário. São Paulo: Companhia das Letras, 1996.

CHARTIER, Roger. Cultura popular: revisitando um conceito historiográfico. Revista Estudos Históricos, Rio de Janeiro, v. 8, n. 16, p. 179-192, dez. 1995. Disponível em: $<$ http://bibliotecadigital.fgv.br/ojs/index.php/reh/article/view/2005/1144>. Acesso em: 12 Ago. 2020 .

CHARTIER, Roger. A História Cultural - entre práticas e representações. $2^{\mathrm{a}}$ ed. Lisboa: Difel, 2002. 
DOSSE, François. A História em Migalhas: dos Annales à Nova História. Bauru, São Paulo: EDUSC, 2003.

GIRON, Luís Antônio. Minoridade Crítica: a ópera e o teatro nos folhetins da Corte: 1826-1861. São Paulo: Editora da Universidade de São Paulo; Rio de Janeiro: Ediouro, 2004.

GOLDBERG, Guilherme; OLIVEIRA, Amanda; MENUZZI, Patrick (orgs.). Transcrições Guanabarinas: antologia crítica - O Paiz (Vol. 1). Porto Alegre: LiquidBook, 2019a.

GOLDBERG, Guilherme; OLIVEIRA, Amanda; MENUZZI, Patrick (orgs.). Transcrições Guanabarinas: antologia crítica - O Paiz (Vol. 2). Porto Alegre: LiquidBook, 2019 b.

GOLDBERG, Guilherme; OLIVEIRA, Amanda; MENUZZI, Patrick (orgs.). Transcrições Guanabarinas: antologia crítica - O Paiz (Vol. 3). Porto Alegre: LiquidBook, 2019c.

GOLDBERG, Guilherme; OLIVEIRA, Amanda; MENUZZI, Patrick (orgs.). Transcrições Guanabarinas: antologia crítica - O Paiz (Vol. 4). Porto Alegre: LiquidBook, 2019d.

GOLDBERG, Luiz Guilherme; OLIVEIRA, Amanda. Apresentação. In: Anais do I Simpósio Internacional Música e Crítica: lembrança aos 80 anos do falecimento de Oscar Guanabarino, 2017, Pelotas. Pelotas: Luiz Guilherme Goldberg, 2019e. p. 1-5. Disponível em <https://wp.ufpel. edu.br/criticamusical/anais/>. Acesso em: 12 Ago. 2020.

GRANGEIA, Fabiana de Araujo Guerra. A crítica de artes em Oscar Guanabarino: artes plásticas no século XIX. 230f. Dissertação (Mestrado em História da Arte). Universidade Estadual de Campinas, Departamento de História do Instituto de Filosofia e Ciências Humanas, São Paulo, 2005.

KAFKA, Franz. O processo. Trad. Marcelo Backes. Porto Alegre: L\&PM, 2009.

LACOUTURE, Jean. A história imediata. In: LE GOFF, Jacques (org.). A História Nova. $4^{\mathrm{a}}$ ed. São Paulo: Martins Fontes, 1988.

PASSAMAE, Maria Aparecida dos Reis Valiatti. Oscar Guanabarino e sua produção crítica de 1922. 131f. Dissertação (Mestrado em Música). Universidade Federal do Rio de Janeiro, Escola de Música, Rio de Janeiro, 2013.

PASSAMAE, Maria Aparecida dos Reis Valiatti. Oscar Guanabarino: produção crítica de 1922. Curitiba: Editora CRV, 2017.

VEYNE, PAUL. Comment on ecrit I'histoire. Paris: Éditions du Seuil, 1978.

\section{Periódicos}

A.B.C.: Política, Actualidades, Questões Sociaes, Lettras e Artes, Rio de Janeiro, Ed. 179, 10 ago. 1918, p. 16.

A.B.C.: Política, Actualidades, Questões Sociaes, Lettras e Artes, Rio de Janeiro, Ed. 659, 22 out. 1927, p. 10.

A ESQUERDA, Rio de Janeiro, Ed. 1002, 17 abr. 1931, p. 6.

CORREIO DA MANHÃ, Rio de Janeiro, Ed. 10400, 30 nov. 1928, p. 5. 
CORREIO DA MANHÃ, Rio de Janeiro, Ed. 11361, 26 dez. 1931, p. 5.

CORREIO DA MANHÃ, Rio de Janeiro, Ed. 11759, 5 abr. 1933, p. 7.

CORREIO DA MANHÃ, Rio de Janeiro, Ed. B12232, 11 out. 1934a, p. 8.

CORREIO DA MANHÃ, Rio de Janeiro, Ed. 12248, 28 out. 1934b, p. 12.

CORREIO DA MANHÃ, Rio de Janeiro, Ed. 12758, 17 jun. 1936, p. 7.

CORREIO DA MANHÃ, Rio de Janeiro, Ed. 14153, 22 dez. 1940, p. 29.

DIÁRIO CARIOCA, Rio de Janeiro, Ed. 860, 17 abr. 1931a, p. 6.

DIÁRIO CARIOCA, Rio de Janeiro, Ed. 1053, 29 nov. 1931b, p. 3.

DIÁRIO CARIOCA, Rio de Janeiro, Ed. 1764, 3 mai. 1934a, p. 3.

DIÁRIO CARIOCA, Rio de Janeiro, Ed. 1766, 5 mai. 1934b, p. 3.

DIÁRIO CARIOCA, Rio de Janeiro, Ed. 2075, 28 abr. 1935a, p. 15.

DIÁRIO CARIOCA, Rio de Janeiro, Ed. 2077, 1 mai. 1935b, p. 14.

DIÁRIO DA NOITE, Rio de Janeiro, Ed. A2326, 30 abr. 1935, p. 5.

DIÁRIO DE NOTÍCIAS, Rio de Janeiro, Ed. 2131, 19 nov. 1933b, p. 7.

DIÁRIO DE NOTÍCIAS, Rio de Janeiro, Ed. 2088, 1 out. 1933c, p. 7.

DIÁRIO DE NOTÍCIAS, Rio de Janeiro, Ed. 3882, 27 set. 1938b, p. 9.

GAZETA DE NOTÍCIAS, Rio de Janeiro, Ed. 232, 8 out. 1926e, p. 3.

JORNAL DO BRASIL, Rio de Janeiro, Ed. 259, 30 out. 1934, p. 15.

JORNAL DO COMMERCIO, Pelo Mundo das Artes, Rio de Janeiro, Ed. 101, 12 abr. 1921, p. 2.

JORNAL DO COMMERCIO, Pelo Mundo das Artes, Rio de Janeiro, Ed. 297, 27 out. 1926b, p. 2.

JORNAL DO COMMERCIO, Pelo Mundo das Artes, Rio de Janeiro, Ed. 270, 12 nov. 1930, p. 2.

JORNAL DO COMMERCIO, Pelo Mundo das Artes, Rio de Janeiro, Ed. 305, 23 dez. 1931, p. 2.

JORNAL DO COMMERCIO, Pelo Mundo das Artes, Rio de Janeiro, Ed. 23, 27 jan. 1932a, p. 2. JORNAL DO COMMERCIO, Pelo Mundo das Artes, Rio de Janeiro, Ed. 05, 6 jan. 1932b, p. 2. JORNAL DO COMMERCIO, Pelo Mundo das Artes, Rio de Janeiro, Ed. 308, 28 dez. 1932c, p. 2. 
JORNAL DO COMMERCIO, Rio de Janeiro, Ed. 117, 17 fev. 1934a, p. 8.

JORNAL DO COMMERCIO, Pelo Mundo das Artes, Rio de Janeiro, Ed. 174, 25 abr. 1934b, p. 2.

JORNAL DO COMMERCIO, Pelo Mundo das Artes, Rio de Janeiro, Ed. 186, 9 mai. 1934c, p. 2.

JORNAL DO COMMERCIO, Pelo Mundo das Artes, Rio de Janeiro, Ed. 14, 17 out. 1934d, p. 2.

JORNAL DO COMMERCIO, Pelo Mundo das Artes, Rio de Janeiro, Ed. 32, 7 nov. 1934e, p. 2. JORNAL DO COMMERCIO, Pelo Mundo das Artes, Rio de Janeiro, Ed. 85, 10 jan. 1934f, p. 2. JORNAL DO COMMERCIO, Pelo Mundo das Artes, Rio de Janeiro, Ed. 14, 16 out. 1935a, p. 2. JORNAL DO COMMERCIO, Pelo Mundo das Artes, Rio de Janeiro, Ed. 20, 23 out. 1935b, p. 2.

JORNAL DO COMMERCIO, Rio de Janeiro, Ed. 76, 30 dez. 1937, p. 13.

JORNAL DO COMMERCIO, Rio de Janeiro, Ed. 265, 10 ago. 1939, p. 9.

O IMPARCIAL, Rio de Janeiro, Ed. 1750, 19 out. 1917, p. 9.

O IMPARCIAL, Rio de Janeiro, Ed. 1250, 19 mai. 1921, p. 5.

O IMPARCIAL, Rio de Janeiro, Ed. 4561, 19 jun. 1925, p. 6.

O JORNAL, Rio de Janeiro, Ed. 1055, 25 jun. 1922a, p. 8.

O IMPARCIAL, Rio de Janeiro, Ed. 1123, 13 set. 1922b, p. 6.

O IMPARCIAL, Rio de Janeiro, Ed. 4034, 29 dez. 1931a, p. 5.

O IMPARCIAL, Rio de Janeiro, Ed. 4008, 28 nov. 1931b, p. 11.

O PAIZ, Rio de Janeiro, Ed. 8619, 9 mai. 1908, p. 5.

O PAIZ, Rio de Janeiro, Ed. 8961, 17 abr. 1909, p. 3.

O PAIZ, Arte e Artistas, Rio de Janeiro, Ed. 10461, 29 mai. 1913a, p. 3.

O PAIZ, Arte e Artistas, Rio de Janeiro, Ed. 10440, 8 mai. 1913b, p. 3.

O PAIZ, Vida Social, Rio de Janeiro, Ed. 10819, 22 mai. 1914c, p. 3.

O PAIZ. Artes e Artistas. Rio de Janeiro. Ed. 11411. 4 jan. 1916b, p. 4.

O PAIZ, Rio de Janeiro, Ed. 13878, 19 out. 1922b, p. 2.

O RADICAL, Rio de Janeiro, Ed. 868, 22 dez. 1934, p. 4. 
O RADICAL, Rio de Janeiro, Ed. 885, 13 jan. 1935a, p. 5.

O RADICAL, Rio de Janeiro, Ed. 972, 30 abr. 1935b, p. 4.

PARA TODOS, Rio de Janeiro, Ed. 408, 9 out. 1926, p. 34.

REVISTA DA SEMANA, Rio de Janeiro, Ed. 01, 17 dez. 1932, p. 24. 